\title{
Imaging in Neurooncology
}

\author{
Andreas H. Jacobs, ${ }^{* \dagger}$ Lutz W. Kracht, $*$ Axel Gossmann, ${ }^{\S}$ Maria A. Rüger, ${ }^{* \dagger}$ Anne V. Thomas, ${ }^{*}$ \\ Alexander Thiel, ** and Karl Herholz ${ }^{*}$ \\ *Max Planck-Institute for Neurological Research, ${ }^{\dagger}$ Center for Molecular Medicine (CMMC), and ${ }^{\ddagger}$ Departments of Neurology \\ and ${ }^{\S}$ Radiology at the University of Cologne, 50931 Cologne, Germany
}

\begin{abstract}
Summary: Imaging in patients with brain tumors aims toward the determination of the localization, extend, type, and malignancy of the tumor. Imaging is being used for primary diagnosis, planning of treatment including placement of stereotaxic biopsy, resection, radiation, guided application of experimental therapeutics, and delineation of tumor from functionally important neuronal tissue. After treatment, imaging is being used to quantify the treatment response and the extent of residual tumor. At follow-up, imaging helps to determine tumor progression and to differentiate recurrent tumor growth from treatment-induced tissue changes, such as radiation necrosis. A variety of complementary imaging methods are currently being used to obtain all the information necessary to achieve the abovementioned goals. Computed tomography and magnetic resonance imaging (MRI) reveal mostly anatomical information on the tumor, whereas magnetic resonance spectroscopy
\end{abstract}

and positron emission tomography (PET) give important information on the metabolic state and molecular events within the tumor. Functional MRI and functional PET, in combination with electrophysiological methods like transcranial magnetic stimulation, are being used to delineate functionally important neuronal tissue, which has to be preserved from treatmentinduced damage, as well as to gather information on tumorinduced brain plasticity. In addition, optical imaging devices have been implemented in the past few years for the development of new therapeutics, especially in experimental glioma models. In summary, imaging in patients with brain tumors plays a central role in the management of the disease and in the development of improved imaging-guided therapies. Key Words: Gliomas, PET, MRS, FHBG, FIAU, molecular imaging.

\section{GENERAL AND MOLECULAR ASPECTS}

Primary brain tumors may arise form various cell types of the brain including glial cells, neurons, neuroglial precursor cells, pinealocytes, the meninges, choroid plexus, pericytes of the vessels, cells of the hypophysis, and lymphocytes. The incidence of primary brain tumors varies between subtypes. The most common primary brain tumors in adults are gliomas and meningiomas. For gliomas, the incidence is six to eight in 100,000 , with approximately $50 \%$ belonging to malignant subtypes. Lower-grade gliomas tend to occur in younger patients, whereas higher-grade tumors are more frequent in older patients. Gliomas are divided histologically into astrocytomas, oligodendrogliomas, mixed gliomas, ependymal tumors, and tumors of the choroid plexus. Grading is

Address correspondence and reprint requests to Professor Dr. A. H. Jacobs, M.D., Laboratory for Gene Therapy and Molecular Imaging, Department of Neurology at the University of Cologne, MPI for Neurological Research, Gleuelerstrasse 50, 50931 Cologne, Germany. Email: Andreas.Jacobs@pet.mpin-koeln.mpg.de. performed according to the World Health Organization (WHO) criteria, taking into account the presence of nuclear changes, mitotic activity, endothelial proliferation, and necrosis. ${ }^{1,2}$ Glioblastoma, corresponding to WHO grade IV, is the most fatal and most common primary brain neoplasm with an incidence of three to four in 100,000 . Approximately $50 \%$ of all gliomas and $20 \%$ of all primary intracranial tumors are glioblastomas. Together with all intracranial neoplasms, the glioblastoma is the second most common cause of death due to an intracranial disease after stroke. Despite aggressive multimodal treatment strategies (surgery, radiation, chemotherapy) median survival of patients with gliomas is limited, depending on grade and age at diagnosis varying from 1 year for glioblastoma, to $2-3$ years for grade III and to 5-10 years for a grade II glioma.

A better understanding of glial tumorgenesis is crucial for the development of specific molecular therapeutic targets to overcome current therapeutic limitations. A complex series of molecular changes occurs, which results in dysregulation of the cell cycle, alterations of 
apoptosis and cell differentiation, in neovascularization as well as tumor cell migration and invasion into the brain parenchyma. Genetic alterations which play an important role in glioma development include a loss, mutation or hypermethylation of the tumor suppressor gene TP53 or other genes involved in the regulation of the cell cycle, such as cyclin-dependent kinase $\mathrm{N} 2 \mathrm{~A} / \mathrm{p} 16$, p14ARF and primitive neuroectodermal tumor (PTEN), as well as activation or amplification of oncogenes and growth factors and/or their receptors, such as MDM2, cyclin-dependent kinase 4, cyclin D1 and D3, epidermal growth factor receptor (EGFR), vascular endothelial growth factor (VEGF), PDGFR [platelet-derived growth factor (PDGF) receptor], and transforming growth factor- $\beta .^{3-5}$ During progression from low-grade astrocytoma (WHO grade II) to anaplastic astrocytoma (WHO grade III) and to glioblastoma multiforme (WHO grade IV) a step-wise accumulation of genetic alterations occurs. Whereas TP53 mutation and PDGF and PDGFR- $\alpha$ overexpression represent early changes during low-grade glioma development, progression to anaplastic astrocytoma is associated with $\mathrm{pRB}$ alteration and loss of heterozygocity ( $\mathrm{LOH}$ ) of $19 \mathrm{q}$, further malignant progression to glioblastoma including $\mathrm{LOH} 10 \mathrm{q}$ and mutations of the PTEN gene. ${ }^{6}$ These secondary glioblastomas, which develop from better differentiated astrocytomas, can be distinguished from primary de novo glioblastomas on the basis of molecular genetic findings ${ }^{7}$ with amplification and/or overexpression of the EGFR, p16 deletion, PTEN mutation, pRB alteration, and LOH 10p and 10q associated with primary glioblastoma. Most importantly, molecular alterations have been identified, which indicate therapeutic response of patients and, thus, are prognostically relevant: anaplastic oligodendrogliomas with LOH $1 p$ and/or LOH 19q are characteristically sensitive to PCV (procarbazine, lomustine, and vincristine) chemotherapy, and patients' survival is significantly prolonged..$^{8-11}$

An overview of the tumors in the cranial cavity is given in Table $1 .^{12-50}$

\section{IMAGING FOR PRIMARY DIAGNOSIS}

Cranial computed tomography (CT) and magnetic resonance imaging (MRI) with and without contrast media are widely used for primary diagnosis of brain tumors. Standard T1- and T2-weighted MRIs detect brain tumors with high sensitivity. Beside primary information on the size and localization of the tumor, especially MRI provides additional information about secondary phenomena such as mass effect, edema, hemorrhage, necrosis, and signs of increased intracranial pressure at high spatial resolution and with high tissue contrast. A set of various MRI acquisitions parameters, like T1-, T2-, proton-, diffusion-, and perfusion-weighted images as well as fluid attenuated inversion recovery (FLAIR) sequences give a characteristic pattern of each tumor depending on tumor type and grade.

Most brain tumors are hypointense on T1-weighted images and hyperintense on FLAIR, T2-, and protonweighted images. Highly proliferative active tumors such as glioblastomas lead to a destruction of the blood-brain barrier (BBB) with subsequent leakage of contrast media (FIG. 1), which is being used for diagnostic purpose in CT and T1-weighted MRI. In contrast, low-grade tumors usually have no or minimal enhancement. The contrastenhancing lesion $(\mathrm{T} 1+\mathrm{Gd})$ corresponds histologically to a hypercellular region with neovascularization, a central hypointense area (T1) is mainly caused by tumor necrosis. Already in the CT-era, biopsies from signal changes in areas surrounding the contrast-enhancing tumor revealed the presence of migrating tumor cells. The tumor volume measured as the volume of T2 hyperintensity is the strongest predictor of overall survival in patients with supratentorial diffuse astrocytoma WHO ${ }^{\circ} \mathrm{II}$ and the only predictor of malignant progression. ${ }^{51}$

Studies on the value of diffusion-weighted imaging (DWI) MRI are ongoing. DWI is able to characterize morphological features including edema, necrosis, and viable tumor tissue by measuring differences in the apparent diffusion coefficient (ADC). DWI might be able to detect areas of tumor infiltration which are not visible on other MRIs. ${ }^{52}$ Furthermore, DWI seems to be useful in providing a greater degree of confidence in distinguishing brain abscesses from cystic or necrotic brain tumors than conventional MRI. ${ }^{53}$

Moreover, dynamic contrast-enhanced MRI is a new and promising imaging tool for measuring physiological tumor properties (e.g., microvascular permeability and plasma volume; FIG. 2). The vascular hyperpermeability of tumor vessels for macromolecular solutes yields a proteinaceous exudate within the tumor interstitium that is considered a favorable milieu for the in-growth of new capillary buds. Changes in tumor vessel permeability and tumor volume as assessed by dynamic contrast enhanced perfusion MRI serve as surrogate marker for angiogenesis and allow the prediction of pathologic tumor grade ${ }^{54,55}$ with high sensitivity but limited specificity. ${ }^{56-58}$

It should be pointed out that the different tissue compartments within a glioblastoma giving rise to different magnetic resonance signals have different gene and protein expression patterns. ${ }^{59}$ Thus, there is potential for imaging-guided proteomics and microarray analysis to identify specific markers of tumor behavior.

Because intratumoral heterogeneity of brain tumors is not adequately reflected in conventional MRI because evaluation of the contrast enhancing lesion can either under- or overestimate the presence of active tumor, magnetic resonance spectroscopy (MRS) and positron 
TABLE 1. Overview of Tumors in the Cranial Cavity

\begin{tabular}{|c|c|c|c|c|}
\hline \multirow{2}{*}{$\begin{array}{l}\text { Tumor Entities (\% of all } \\
\text { primary brain tumors) }\end{array}$} & \multirow[b]{2}{*}{$\mathrm{MRI} / \mathrm{CT}$} & \multicolumn{2}{|c|}{ PET } & \multirow[b]{2}{*}{ Ref. } \\
\hline & & FDG* & Methionine $^{\dagger}$ & \\
\hline \multicolumn{5}{|l|}{ 1. Gliomas } \\
\hline $\begin{array}{l}\text { Pilocytic astrocytoma } \\
\text { WHO I }^{\circ}(<3 \%)\end{array}$ & $\begin{array}{l}\text { Cystic tumor with focal contrast } \\
\text { enhancement }\end{array}$ & $\begin{array}{l}\text { Variable, focally } \\
\text { increased }\end{array}$ & Up to 2 -fold & $\begin{array}{l}18 \\
21\end{array}$ \\
\hline $\begin{array}{l}\text { Astrocytoma } \mathrm{WHO}^{\circ} \mathrm{II}^{\circ} \\
(<5 \%)\end{array}$ & $\begin{array}{l}\text { T1: slightly hypointense T2: } \\
\text { hyperintense }\end{array}$ & Decreased & 1 - to 2 -fold & See text \\
\hline $\begin{array}{l}\text { Anaplastic astrocytoma } \\
\text { WHO } \text { III }^{\circ}(<5 \%)\end{array}$ & $\begin{array}{l}\text { T1: hypointense } \mathrm{T} 2 \text { : hyperintense } \\
\text { Contrast enhancement and perifocal } \\
\text { edema }\end{array}$ & Variable & 2- to 3-fold & \\
\hline $\begin{array}{l}\text { Glioblastoma WHO IV }{ }^{\circ} \\
\quad(20-25 \%)\end{array}$ & $\begin{array}{l}\text { Irregular tumor border T1: central } \\
\text { necrosis hypointense T2: perifocal } \\
\text { edema hyperintense contrast } \\
\text { enhancement }\end{array}$ & Increased & $>2.5$-fold & \\
\hline $\begin{array}{l}\text { Oligodendroglioma WHO } \\
\text { II }^{\circ} / \mathrm{III}^{\circ}(<5 \%)\end{array}$ & $\begin{array}{l}\text { Inhomogenous tumor with focal con- } \\
\text { trast enhancement and calcifications } \\
\text { on CCT in } 70-90 \%\end{array}$ & $\begin{array}{l}\text { Decreased/ } \\
\text { increased }\end{array}$ & $>2.5$-fold & \\
\hline $\begin{array}{l}\text { Oligoastrocytoma WHO } \\
\text { II }^{\circ} / \mathrm{III}^{\circ}(<5 \%)\end{array}$ & & $\begin{array}{l}\text { Decreased/ } \\
\text { increased }\end{array}$ & 2- to 3-fold & \\
\hline Ependymomas $(2-3 \%)$ & $\begin{array}{l}\text { Characteristic localization in IVth } \\
\text { ventricle or intramedullary; } \\
\text { heterogenous, cystic, hemorrhages }\end{array}$ & Decreased & 1.3 - to 2.7 -fold & $\begin{array}{l}40 \\
50 \\
36\end{array}$ \\
\hline $\begin{array}{l}\text { Choroid plexus papilloma } \\
\qquad(<1 \%)\end{array}$ & $\begin{array}{l}\text { Characteristic localization in ventricles; } \\
\text { sharp tumor border; gross contrast } \\
\text { enhancement }\end{array}$ & N.A. & N.A. & \\
\hline Gliomatosis cerebri & $\begin{array}{l}\text { diffusely infiltrating; hyperintense (T2, } \\
\text { FLAIR) }\end{array}$ & N.A. & N.A. & \\
\hline \multicolumn{5}{|l|}{$\begin{array}{l}\text { 2. Neuronal and glio } \\
\text { neuronal tumors }\end{array}$} \\
\hline $\begin{array}{l}\text { Dysembryoplastic } \\
\text { neuroepithelial tumor } \\
(<1 \%)\end{array}$ & $\begin{array}{l}\text { Multicystic subcortical tumors with } \\
\text { focal contrast enhancement }\end{array}$ & $\begin{array}{l}\text { Decreased benzoc } \\
\text { density as poss } \\
\text { epileptogenicity }\end{array}$ & $\begin{array}{l}\text { azepine receptor } \\
\text { le reason for }\end{array}$ & $\begin{array}{l}45 \\
27 \\
43\end{array}$ \\
\hline $\begin{array}{l}\text { Dysplastic gangliocytoma } \\
(<1 \%)\end{array}$ & & Increased & Increased & \\
\hline Ganglioglioma $(<1 \%)$ & $\begin{array}{l}\text { Cortical localization, solid or cystic } \\
\text { with calcifications and little contrast } \\
\text { enhancement }\end{array}$ & $\begin{array}{l}\text { Variable, de- } \\
\text { pending on } \\
\text { WHO grade }\end{array}$ & N.A. & $\begin{array}{l}26 \\
44 \\
34\end{array}$ \\
\hline $\begin{array}{l}\text { Central neurocytoma } \\
\quad(<1 \%)\end{array}$ & $\begin{array}{l}\text { Sharp tumor border, inhomogenous } \\
\text { with cysts, necroses, calcifications, } \\
\text { positive contrast enhancement }\end{array}$ & $\begin{array}{l}\text { Increased, de- } \\
\text { pending on } \\
\text { proliferative } \\
\text { activity }\end{array}$ & increased & $\begin{array}{l}35 \\
41\end{array}$ \\
\hline \multicolumn{5}{|l|}{$\begin{array}{l}\text { 3. Tumors of the pineal } \\
\text { gland }(<1 \%)\end{array}$} \\
\hline Pineocytoma & & N.A. & N.A. & \\
\hline Pineoblastoma & Contrast enhancing & Increased & N.A. & 12 \\
\hline Germinoma & Isointense with contrast enhancement & N.A. & N.A. & \\
\hline 4. Embryogenic tumors & & & & \\
\hline $\begin{array}{l}\text { Medulloblastoma } \\
\quad(20-25 \% \\
<15 \text { y.o.; } 1 \%>20 \text { y.o. })\end{array}$ & $\begin{array}{l}\text { Cystic tumor in } 4 \text { th ventricle }(75 \%) \text { or } \\
\text { cerebellum }(25 \%) \text {; T1: hypointense; } \\
\text { T2: hyperintense; moderate contrast } \\
\text { enhancement }\end{array}$ & $\begin{array}{l}\text { Strongly } \\
\text { increased }\end{array}$ & Increased & 24 \\
\hline $\begin{array}{l}\text { Primitive neuroecto- } \\
\text { dermal tumors (PNET) }\end{array}$ & & $\begin{array}{l}\text { Decreased; rela- } \\
\text { tively in- } \\
\text { creased in } \\
\text { spinal } \\
\text { localization }\end{array}$ & N.A. & $\begin{array}{l}24 \\
33\end{array}$ \\
\hline
\end{tabular}


TABLE 1. Continued

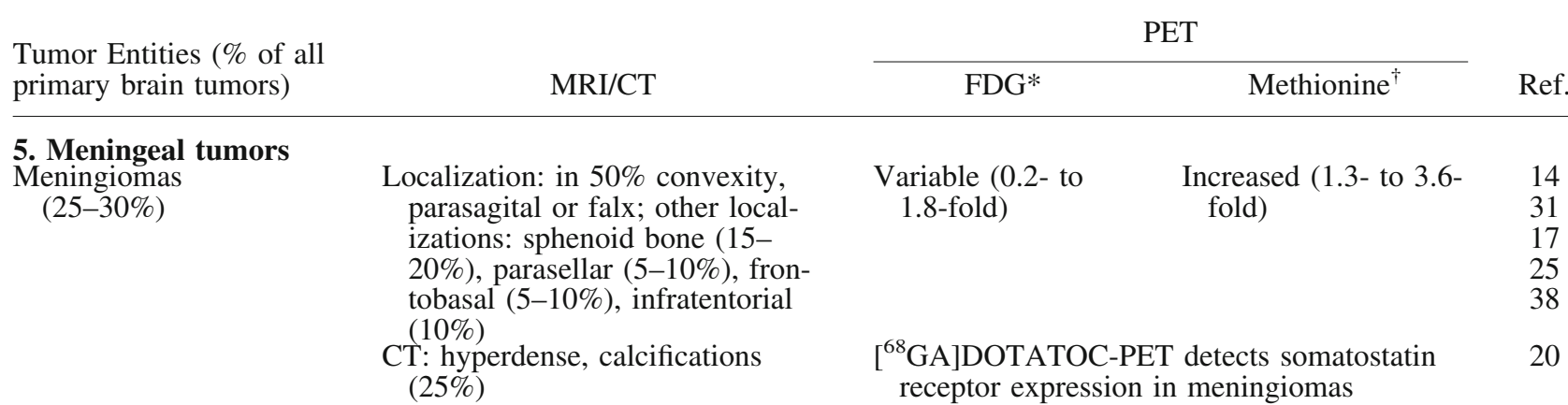

Hemangiopericytoma $(<0.5 \%)$

MRI: T1 isointense; T2 hypointense; infiltration of bone; dural artery; dural tail sign

CT/MRI: contrast enhancement and peritumoral edema

6. Tumors of the region of the sella

Craniopharyngioma $(<2 \%)$

Adenomas of the hypophysis $(5-8 \%)$

Intrasellar (30\%) and suprasellar (70\%); cystic, calcifications, contrast enhancement

Microadenomonas on T1 hypo- or isointense; slow contrast enhancement; macroadenomas on $\mathrm{T} 1$ and $\mathrm{T} 2$ isointense with strong contrast enhancement

\section{Tumors of cranial} nerves

Neurinoma (6-8\%)

\section{Lymphomas}

Primary lymphoma of the CNS

(2-5\%)
Cranial nerve VIII (90\%), others: V, VII, IX-XII; sharp tumor border, T1 hypointense, T2 hyperintense, strong contrast enhancement

Localization around ventricles and in basal ganglia; in 50\% multiple sites; on T1 and T2 isointense, homogenous contrast enhancement, perifocal edema

\section{Metastatic tumors $(\approx 20 \%$} of all brain tumors)

Lung, breast, melanoma, gastrointestinal, hypernephroma

Supratentorial $(90 \%)$ localized at inner border of cortex; infratentorial $(10 \%)$; 50-70\% multiple; 30-50\% single; T1 hyperintense, T2 hypointense, ring-like contrast enhancement
Decreased

Increased

- $\left[{ }^{18} \mathrm{~F}\right]$ FDG-PET variable depending on histo-

-Specific binding to D2-receptors on

${ }^{18}$ F]FESP-PET differentiates adenomas of hypophysis from perisellar meningiomas and craniopharyngiomas;

-Specific increase in monoaminooxidase activity on $\left[{ }^{11} \mathrm{C}\right]$ Deprenyl-PET differentiates adenomas of hypophysis from perisellar meningiomas by specific increased monoaminooxidase activity

Iso- or

hypo-metabolic

Only slight increase

Increased; FDG-PET Increased 48 allows differential 22 diagnosis from $\quad 46$ toxoplasmosis

Variable; screening N.A. for metastasis with $\left[{ }^{18} \mathrm{~F}\right] \mathrm{FDG}$ is not recommended

$\left[{ }^{68} \mathrm{GA}\right]$ DOTATOC-PET detects somatostatin receptor positive metastasis of carcinoid tumors

\footnotetext{
$*=\left[{ }^{18} \mathrm{~F}\right] \mathrm{FDG}$ in comparison to cortical cerebral metabolic rate of glucose (CMRGlc).

$\dagger=\left[{ }^{11} \mathrm{C}\right] \mathrm{MET}$ in comparison to contralateral control region.

N.A. $=$ Not available.

$\left[{ }^{18} \mathrm{~F}\right] \mathrm{FESP}=\left[{ }^{18} \mathrm{~F}\right]$ fluoro-ethyl-spiperone.

$\left[{ }^{68} \mathrm{GA}\right]$ DOTATOC $=\left[{ }^{68} \mathrm{GA}\right]-1,4,7,10$-tetraazacyclododecan- $N, N^{\prime}, N^{\prime \prime}, N^{\prime \prime \prime}$-tetraacetacid-D-Phe-Tyr-octreoid.
} 


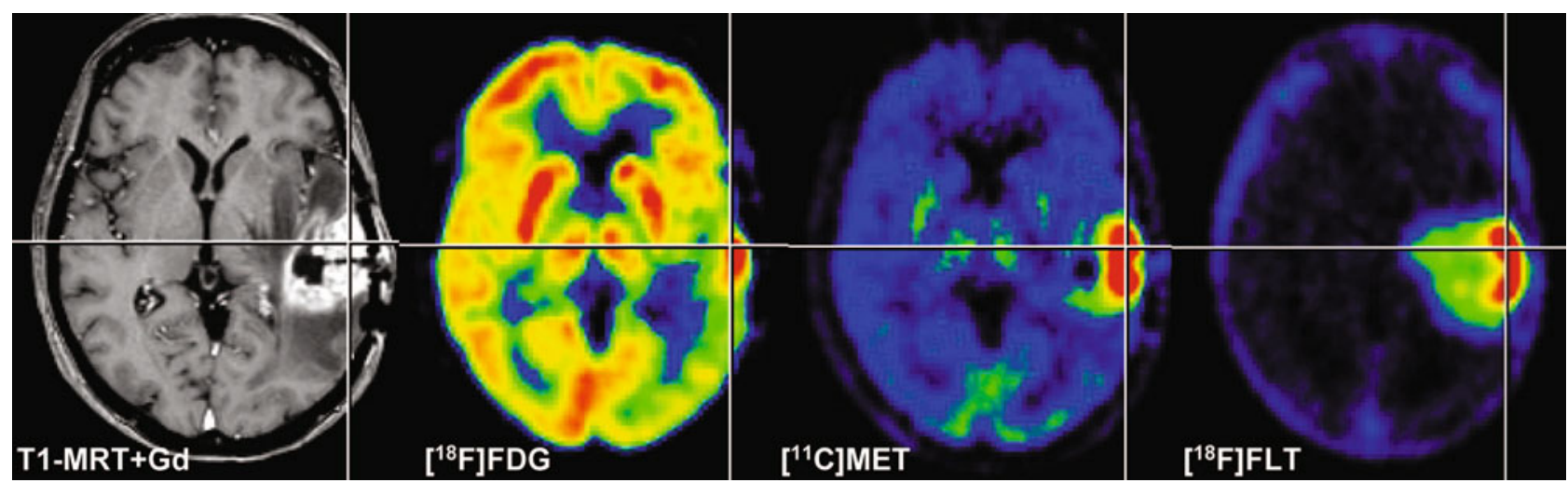

FIG. 1. Parameters of interest in the noninvasive diagnosis of brain tumors. Alteration of the blood-brain barrier and the extent of peritumoral edema are detected by MRI. Signs of increased cell proliferation can be observed by means of multi-tracer PET imaging using $\left[{ }^{18} \mathrm{~F}\right] \mathrm{FDG},\left[{ }^{11} \mathrm{C}\right] \mathrm{MET}$, and $\left[{ }^{18} \mathrm{~F}\right] \mathrm{FLT}$ as specific tracers for glucose consumption, amino acid transport and DNA synthesis, respectively. Secondary phenomena, such as inactivation of ipsilateral cortical cerebral glucose metabolism, may be observed $\left(\left[{ }^{18} \mathrm{~F}\right] \mathrm{FDG}\right)$ and are of prognostic relevance. $\mathrm{Gd}=$ gadolinium. Reproduced with permission from Jacobs AH. PET in gliomas. In: Neuroonkologie (Schlegel U, Weller M, Westphal M, eds), pp 72-76. Copyright @ 2003, Thieme-Verlag. All rights reserved. ${ }^{186}$

emission tomography (PET) are being performed to gain additional information on metabolic and molecular tumor markers. MRS gives additional information on the real extent of the tumor and on tissue metabolites, such as $\mathrm{N}$-acetylaspartate (NAA), creatine, choline, and lactate. ${ }^{60}$ The increase of choline-containing compounds and of NAA appears to correlate best with the degree of tumor infiltration. ${ }^{61,62}$ The appearance of creatine differentiates gliomas from metastasis, which generally lack creatine. ${ }^{63}$ An improved automated MRS analysis approach (nosologic imaging) enables correct differentiation between low-grade glioma, high-grade glioma, meningiomas, metastasis, necrosis, and healthy tissue in up to $90 \%$ of cases and shall facilitate a noninvasive diagnosis of lesion type ${ }^{64,65}$ Disadvantages of MRS include its low spatial resolution, which cannot fully address the anatomical and contrast heterogeneity of brain tumors observed with MRI.

The role of PET has been primarily investigated in patients with gliomas as the most frequent and most difficult to treat primary brain tumors. PET reveals highly specific quantitative information on the metabolic state of gliomas. ${ }^{66-68}$ PET allows the quantitative localization of expression of endogenous or exogenous genes coding for enzymes or receptors by measuring the accumulation or binding of the respective enzyme substrates or receptor binding compounds. ${ }^{69-71}$ Depending on the radiotracer, various molecular processes can be visualized by PET, most of them relating to an increased cell proliferation within gliomas (FIG. 1). Radiolabeled 2- $\left[{ }^{18} \mathrm{~F}\right]$ fluoro-2-deoxy-D-glucose $\left(\left[{ }^{18} \mathrm{~F}\right] \mathrm{FDG}\right)$, methyl$\left[{ }^{11} \mathrm{C}\right]$-L-methionine $\left(\left[{ }^{11} \mathrm{C}\right] \mathrm{MET}\right)$ and $3^{\prime}$-deoxy-3'-
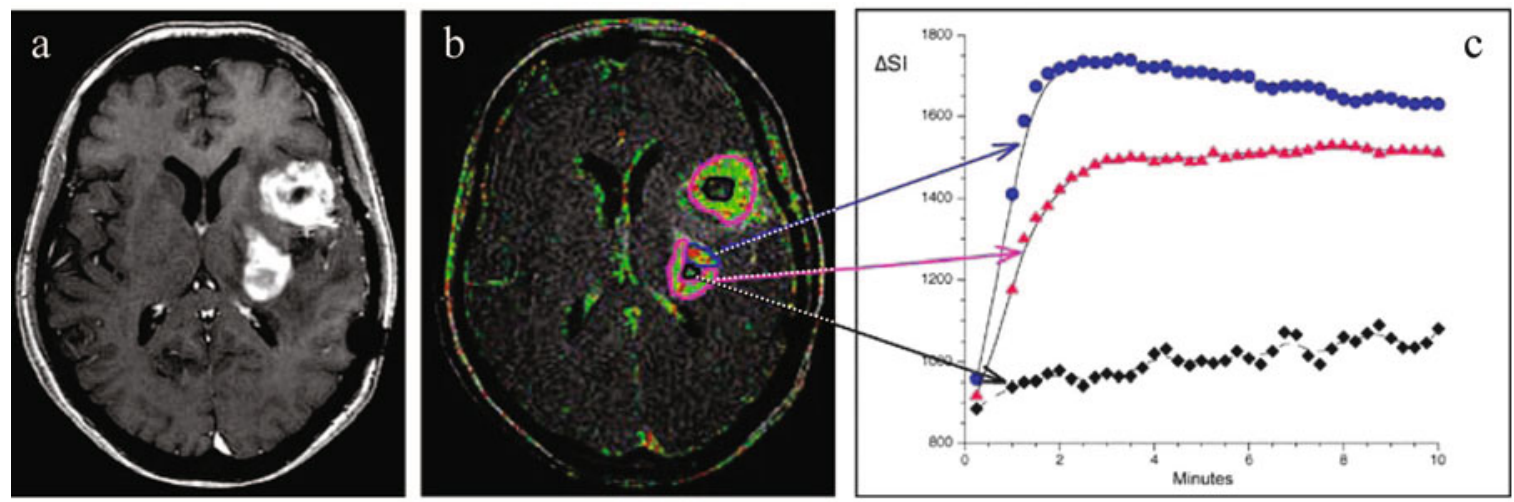

FIG. 2. Representative image of an axial $T_{1}$-weighted postcontrast sequence (a), a corresponding color coded "relative enhancement map" of a dynamic contrast enhanced three-dimensional $\mathrm{T}_{1}$-weighted sequence (b), and signal intensity (SI) curves of different tumor areas (c) in a patient with glioblastoma multiforme. Areas with a strong uptake of contrast media show high SI values during the first 2 min with a subsequent wash out phenomena (blue region of interest and blue curve), which is indicative of a substantial microvascular leak with progressive accumulation of contrast agent in the tumor interstitial space. Areas with lower microvascular permeability values show a less pronounced tumor enhancement (pink region of interest and pink curve), whereas necrotic tumor areas only show a minor uptake of contrast media (black region of interest and black curve). Tumor heterogeneity and different areas of microvascular permeability within an individual tumor mass are characteristic findings for malignant tumors and are only visible on dynamic imaging sequences (b) and not on conventional MRls (a). 
$\left[{ }^{18} \mathrm{~F}\right]$ fluoro-L-thymidine $\left(\left[{ }^{18} \mathrm{~F}\right] \mathrm{FLT}\right)$ are taken up by proliferating gliomas depending on their tumor grade as a reflection of increased activity of membrane transporters for glucose, $\left(\left[{ }^{18} \mathrm{~F}\right] \mathrm{FDG}\right)$, amino acids $\left(\left[{ }^{11} \mathrm{C}\right] \mathrm{MET}\right)$, and nucleosides $\left(\left[{ }^{18} \mathrm{~F}\right] \mathrm{FLT}\right)$ as well as increased expression of cellular hexokinase $\left(\left[{ }^{18} \mathrm{~F}\right] \mathrm{FDG}\right)$ and thymidine kinase $\left(\left[{ }^{18} \mathrm{~F}\right] \mathrm{FLT}\right)$ genes, which specifically phosphorylate $\left[{ }^{18} \mathrm{~F}\right] \mathrm{FDG}$ and $\left[{ }^{18} \mathrm{~F}\right] \mathrm{FLT}$, respectively.

$\left[{ }^{18}\right.$ F]FDG-PET depicts the rate of glucose uptake and has been used to detect the metabolic differences between normal brain tissue, low-grade and high-grade gliomas, and radionecrosis. ${ }^{72-74}$ Increased intratumoral glucose consumption correlates with tumor grade, cell density, biological aggressiveness, and survival of patients in both primary and recurrent gliomas. ${ }^{74-79}$ In general, low-grade tumors have a metabolic activity similar to white matter and higher-grade tumors, similar to gray matter (FIG. 3). A tumor-to-white matter ratio greater than 1.5 and tumor-to-gray matter ratio less than 0.6 were found to be indicative of high grade tumors with high sensitivity (94\%) and limited specificity (77\%). ${ }^{80}$ Relatively benign tumors with a high FDG uptake included pilocytic astrocytoma and ganglioglioma. Pilocytic astrocytomas have a good prognosis despite exhibiting high FDG uptake and positive contrast enhancement (MRI) due to the presence of metabolically active fenestrated endothelial cells. The limited differentiation between tumor and normal gray matter by $\left[{ }^{18} \mathrm{~F}\right]$ FDG-PET may be improved by scanning at delayed intervals 3-7 $\mathrm{h}$ after tracer injection. ${ }^{81}$ However, due to the relative high background levels of cortical glucose consumption more specific radiotracers for glioma diagnosis were developed.

The radiolabeled amino acids methyl- $\left[{ }^{11} \mathrm{C}\right]-\mathrm{L}-\mathrm{methio}-$ nine $\left(\left[{ }^{11} \mathrm{C}\right] \mathrm{MET}\right),\left[{ }^{11} \mathrm{C}\right]$-tyrosine, $\left[{ }^{18} \mathrm{~F}\right]$ fluoro-tyrosine and $\mathrm{O}-\left(2-\left[{ }^{18} \mathrm{~F}\right]\right.$-fluoroethyl $)$-L-tyrosine have been shown to be more specific tracers for tumor detection and tumor delineation due to their low uptake in normal brain. ${ }^{21,78,82-86}$ The increased methionine uptake (factor of 1.3-3.5 in comparison with a contralateral control region) is related to increased transport mediated by type $\mathrm{L}$ amino acid carriers. ${ }^{87,88}\left[{ }^{11} \mathrm{C}\right]$ MET-uptake correlates to cell proliferation in vitro, the expression of Ki-67 and proliferating cell nuclear antigen, as well as to microvessel density, explaining its role as a marker for active tumor proliferation. ${ }^{82,89,90}$ The intensity of $\left[{ }^{11} \mathrm{C}\right] \mathrm{MET}$ uptake differentiates between $\mathrm{WHO} \mathrm{II}^{\circ}$ and $\mathrm{WHO} \mathrm{III}^{\circ} /$ IV $^{\circ}$ gliomas (FIG. 3). ${ }^{21,86}$ Uptake is increased not only in solid parts of the tumor but also in the infiltration area. ${ }^{91,92} \mathrm{In} 80 \%$ of gliomas WHO $\mathrm{II}^{\circ}\left[{ }^{11} \mathrm{C}\right]$ MET-uptake is greater than 1.5 -fold of the normal brain tissue, ${ }^{21}$ whereas glucose metabolism is reduced compared with gray matter. Most studies indicated that $\left[{ }^{11} \mathrm{C}\right] \mathrm{MET}$-uptake is inversely correlated to prognosis, ${ }^{93-95}$ but due to significant $\left[{ }^{11} \mathrm{C}\right]-$ MET uptake also in most low-grade
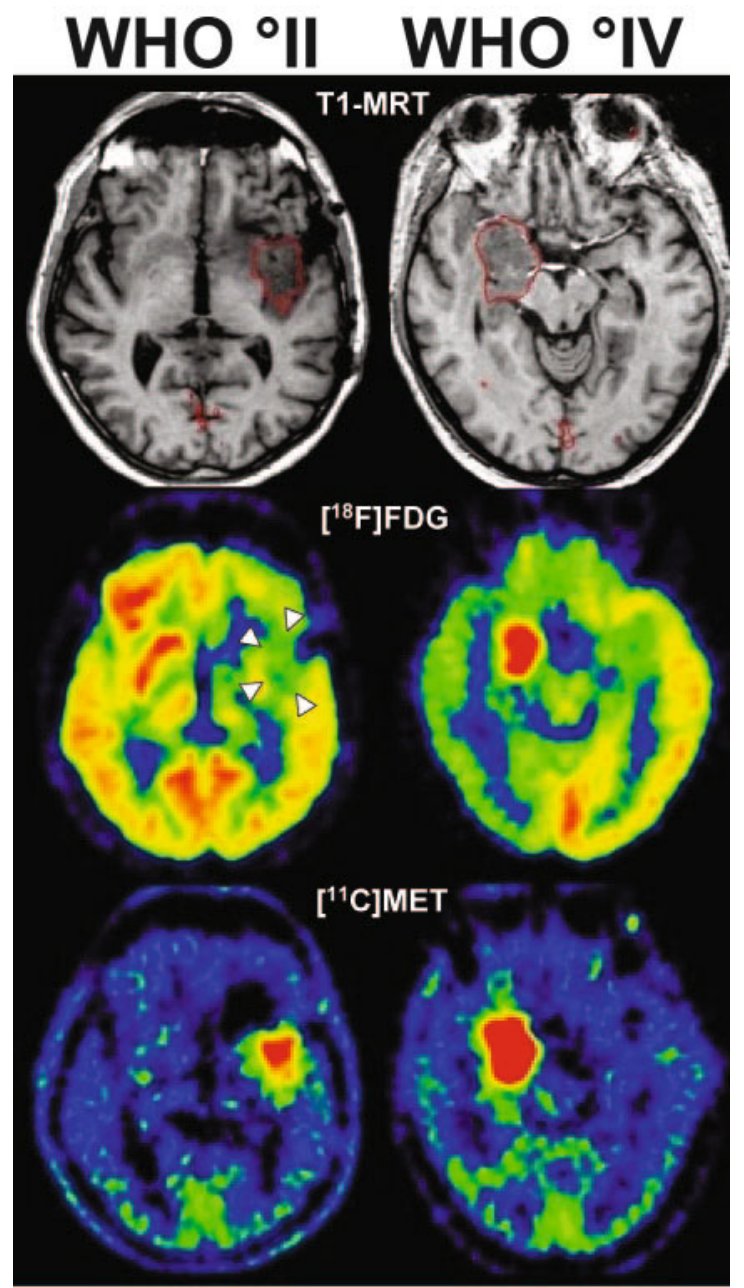

FIG. 3. Noninvasive differentiation between low- and highgrade glioma. In low-grade gliomas $\left(\mathrm{WHO} \mathrm{II}^{\circ}\right.$ ) glucose metabolism is similar to white matter (arrows) and amino acid uptake is only moderately increased. In high-grade gliomas (GBM; WHO IV), both glucose metabolism and amino acid uptake are increased. Reproduced with permission from Jacobs AH. PET in gliomas. In: Neuroonkologie (Schlegel U, Weller M, Westphal M, eds), pp 72-76. Copyright (C) 2003, Thieme-Verlag. All rights reserved. ${ }^{186}$

gliomas this relation is less close than with FDG. For WHO III $/ \mathrm{IV}^{\circ}$ gliomas increased $\left[{ }^{11} \mathrm{C}\right]$ MET-uptake is directly correlated to increased $\left[{ }^{18} \mathrm{~F}\right] \mathrm{FDG}$ uptake $\mathrm{e}^{78,96}$ and exceeds the area of involvement depicted by Gd-enhanced MRI. ${ }^{97}$ It should be pointed out that increased $\left[{ }^{11} \mathrm{C}\right] \mathrm{MET}$ uptake also depends on tumor type, with oligodendrogliomas accumulating more radiotracer than astrocytomas from the same histological grade. ${ }^{21,78,98}$ Disadvantages of $\left[{ }^{11} \mathrm{C}\right]$ methionine are its uptake in acutely ischemic and inflammatory brain tissue ${ }^{99}$ as well as its short half-life.

The third parameter, which can be noninvasively assessed by PET is the incorporation of nucleosides into DNA in proliferating cells. Radiolabeled thymidine $\left(\left[{ }^{3} \mathrm{H}\right] \mathrm{TdR}\right)$ is the gold standard for determination of cell proliferation in cell culture, and to date ${ }^{11} \mathrm{C}$ - and ${ }^{18} \mathrm{~F}$ - 
labeled thymidine compounds have been radiosynthesized to allow a noninvasive assessment of tumor proliferation as well as early response to chemotherapy by PET. $3^{\prime}$-deoxy- $3^{\prime}-\left[{ }^{18}\right.$ F $]$ fluoro-L-thymidine $\left(\left[{ }^{18} \mathrm{~F}\right] \mathrm{FLT}\right)$ is stable in vivo and has been used for the evaluation of tumor proliferation primarily in extra-cranial tissues. Unpublished results in patients with gliomas indicate that $\left[{ }^{18} \mathrm{~F}\right] \mathrm{FLT}$ is a promising tracer to study glioma proliferation especially in areas with high $\left[{ }^{18} \mathrm{~F}\right] \mathrm{FDG}$ background. Relative $\left[{ }^{18} \mathrm{~F}\right] \mathrm{FLT}$ uptake within gliomas is greater than relative $\left[{ }^{11} \mathrm{C}\right]$ MET uptake (FIG. 1), indicating the possible role of $\left[{ }^{18} \mathrm{~F}\right] \mathrm{FLT}$ as a more specific tumor marker than $\left[{ }^{18} \mathrm{~F}\right] \mathrm{FDG}$ and $\left[{ }^{11} \mathrm{C}\right] \mathrm{MET} .{ }^{100-103}$ The overall goal is to be able to quantify chemotherapeutic effects early (within days to weeks).

A summary of MRI and PET findings in human brain tumors are given in Table 1.

\section{IMAGING FOR PLANNING RESECTION AND RADIATION THERAPY INCLUDING DELINEATION FROM FUNCTIONAL NEURONAL TISSUE}

MRI is the method of choice for tumor localization. Delineation of the tumor in three dimensions (sagittal, coronal, and axial) allows the selection of the best operative procedure. CT is being used for detection of calcifications in oligodendrogliomas, meningiomas, or craniopharyngiomas and for tumors that are located at the base of the skull. Magnetic resonance angiography is being used alone or together with conventional angiography to study the location of the tumor with respect to its vascularization. In selected patients and in specialized institutions, MRS and PET are being used in conjunction with MRI to define the real extend of the tumor. ${ }^{91,104-107}$ Most importantly, tumors that are located in eloquent areas require preoperative functional imaging by functional MRI (fMRI) or functional PET (FIG. 4). ${ }^{108-115}$ These combined imaging procedures are especially important in those patients where tumor growth has led to changes within the neuronal network as a result of functional brain plasticity. These changes consist either of a displacement of functional important neuronal tissue (like language areas) surrounding the lesion or in the recruitment of new brain areas that are usually not involved in the performance of a certain task. ${ }^{114-116}$ Functional imaging studies alone can provide information about which brain areas are involved in the performance of a certain behavioral task but can not answer the diagnostically important question of whether a certain brain area is essential for that task. This additional information can be obtained by combining functional brain images with transcranial magnetic stimulation, an electrophysiological method to temporarily interfere with normal brain function ${ }^{116 \mathrm{a}}$. A distance of $1 \mathrm{~cm}$ or more between

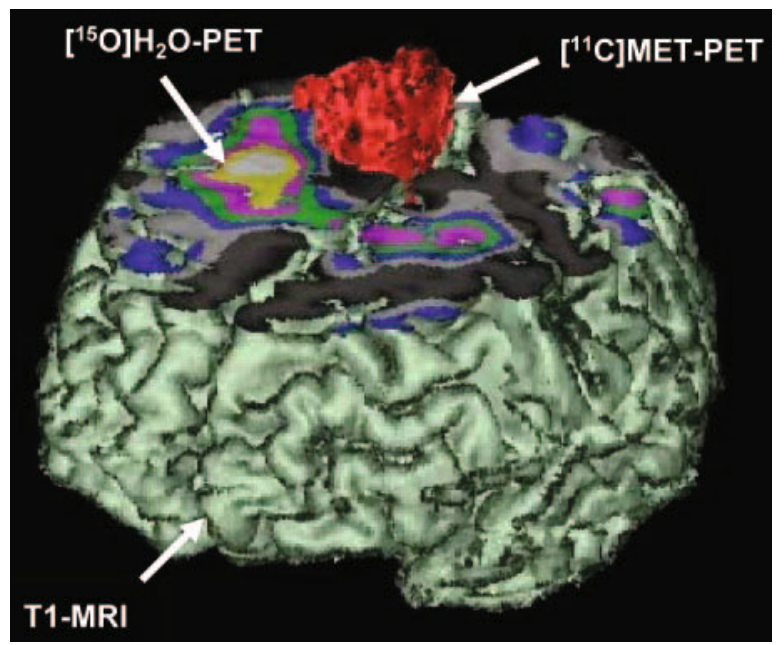

FIG. 4. Preoperative differentiation of tumor tissue from functionally important neuronal tissue through multimodal and multitracer imaging. These combined imaging procedures shall guide the neurosurgeon to operate as much tumor as possible but at the same time to leave the functionally important tissue intact. Reproduced with permission from Jacobs et al. Molecular imaging of gliomas. Mol Imaging 1:309-355. Copyright (C) 2002, MIT Press Journals. All rights reserved. ${ }^{67}$

the functional relevant cortex, as delineated by fMRI, and the tumor significantly reduces the risk of postoperative loss of function. ${ }^{117}$ The evaluation of the cerebral reorganization of motor function is an essential step in predicting the risk of motor deficits in patients with an indication for operative treatment. ${ }^{118}$ Only these combined imaging technologies will allow to maximize the spatial extent of tumor treatment and to simultaneously preserve functional relevant tissue. ${ }^{119}$ Moreover, metabolic or molecular information derived from PET or SPECT studies is being used in some institutions for the exact planning for radio- ${ }^{105}$ and gene therapy. ${ }^{120,121}$ This is of special importance because tumor volume as depicted by contrast-enhanced MRI is always smaller than the tumor volume as depicted by $\left[{ }^{11} \mathrm{C}\right]$ MET-PET .97 Whether $\left[{ }^{11} \mathrm{C}\right]$ MET-PET-guided extended fields of radiation have a significant influence on time to progression and overall survival has to be proven in future studies.

In recent years, diffusion tensor white matter fiber tracking and intraoperative MRI have become promising tools to guide the neurosurgeon intraoperatively. These techniques allow to maximize tumor resection without additional morbidity ${ }^{122,123}$ by avoiding lesions to fiber tracts like the pyramidal tract. ${ }^{124-126}$

\section{IMAGING FOR PLANNING STEREOTAXIC BIOPSY AND TARGETED APPLICATION OF THERAPEUTICS}

Brain tumors may consist of different parts, which are heterogenous with respect to tumor grading; thus, lowand high-grade areas may be present within the same 
tumor. Stereotaxic biopsy aims at the tumor sites with the highest tumor grade. Therefore, suitable targets for biopsy will have positive contrast enhancement on T1-weighted MRI, a high choline-peak on MRS, hypermetabolism on $\left[{ }^{18} \mathrm{~F}\right]$ FDG-PET, ${ }^{127-129}$ and high accumulation of $\left[{ }^{11} \mathrm{C}\right] \mathrm{me}-$ thionine. $^{92,130,131}$ Moreover, in the development of new experimental therapies, multimodal imaging procedures help identify the most active tumor parts for targeted placement of local infusion catheters (FIG. 5). In a phase I clinical gene therapy trial, imaging the expression of endogenous genes by $\left[{ }^{18} \mathrm{~F}\right]$ FDG- and $\left[{ }^{11} \mathrm{C}\right] \mathrm{MET}-\mathrm{PET}$ as direct measures for the respective gene expression and as surrogate markers for proliferation and tumor cell density was used to identify the biological active tumor portion as proper target tissue and to measure response to gene therapy (FIG. 5). ${ }^{120,121}$

In trials employing convection-enhanced delivery of local chemotherapeutics, DWI is being used to assess the convective process and routine diagnostic MR imaging to identify the tumor response. ${ }^{132}$

\section{IMAGING FOR DETERMINATION OF TREATMENT EFFECT, TUMOR PROGRESSION, AND DIFFERENTIATION OF RECURRENT TUMOR FROM RADIATION NECROSIS}

The effects of treatment should ideally be visualized with the same imaging parameters that have been used before therapy (FIG. 5). However, there are several limitations inherent in each imaging modality. On contrastenhanced MRI, residual tumor and postsurgical changes can both result in abnormal enhancement. Therefore, MRI cannot be used postoperatively after day 3 and for several weeks because the surgical damage of the BBB, with subsequent leakage of contrast media, leads to a false-positive indicator of the presence of residual or recurrent tumor. Moreover, conventional MRI techniques usually fail to detect early effects of radio- and chemotherapy because individual treatment effects are only visible after more than 12 months, ${ }^{133-135}$ with a substantial interobserver variability in the assessment of treatment response. ${ }^{136}$ Especially after the application of biologically active agents (gene therapy vectors, toxins), the value of conventional MRI to detect therapy-specific changes of tumor viability is limited ${ }^{137}$ as reviewed previously. ${ }^{138}$

In contrast, dynamic contrast enhanced MRI, as a surrogate marker for angiogenesis, is useful for monitoring antiangiogenic therapies in brain tumors. ${ }^{139}$ Moreover, diffusion-weighted MRI detects therapy-induced water diffusion changes and has been suggested to provide an early surrogate marker for quantification of treatment response. ${ }^{140}$ It was found that low values for the ADC indicating high tissue viability imply better response to
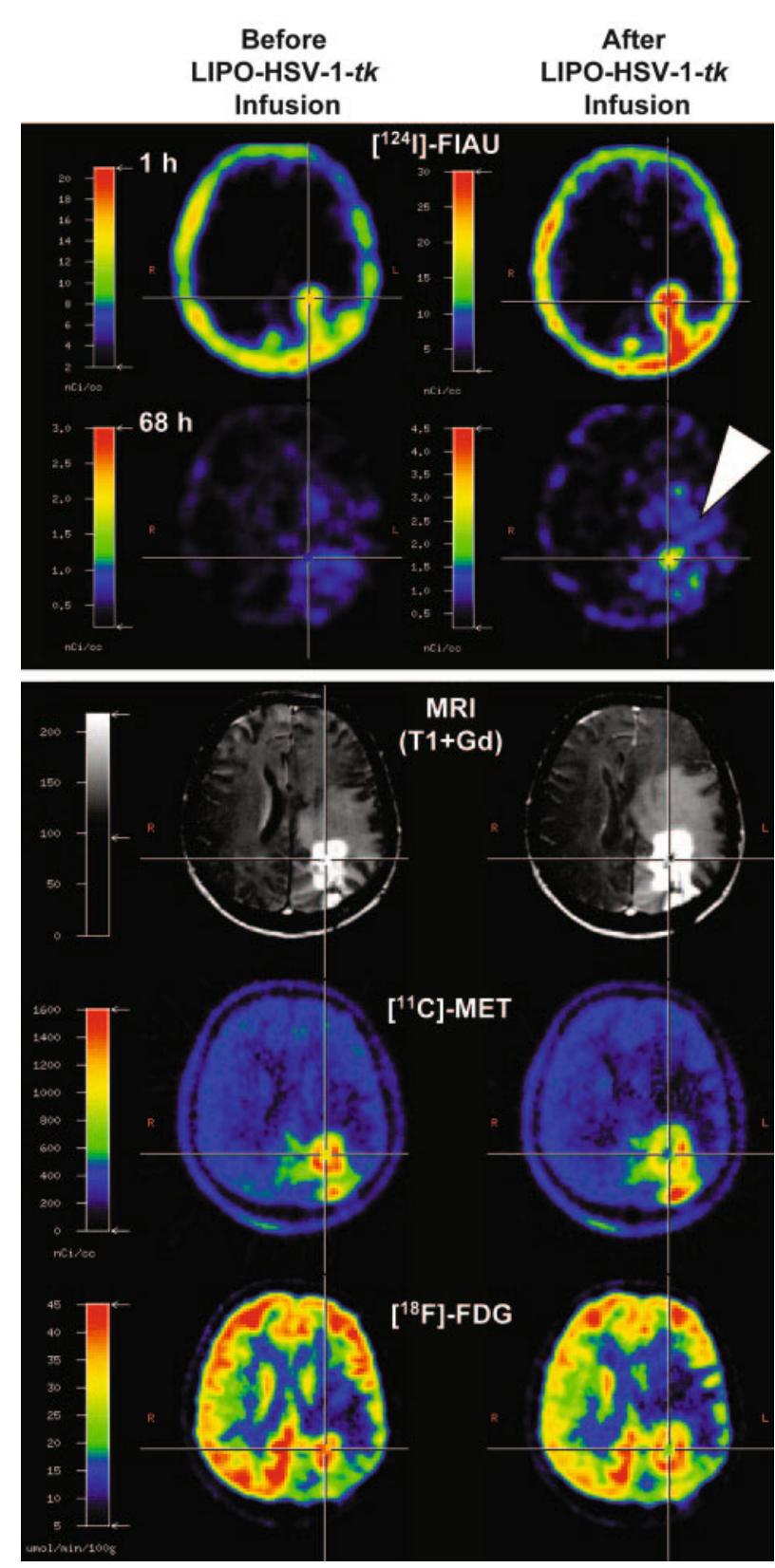

FIG. 5. Multimodal imaging for the establishment of imagingguided experimental treatment strategies. Coregistration of $\left[{ }^{18} \mathrm{~F}\right] \mathrm{FIAU}-,\left[{ }^{11} \mathrm{C}\right] \mathrm{MET}-,\left[{ }^{18} \mathrm{~F}\right] \mathrm{FDG}-\mathrm{PET}$ and MRI before (left column) and after (right column) targeted application (stereotactic infusion) of a gene therapy vector. The region of specific [ $\left.{ }^{124} \mathrm{I}\right]-$ FIAU retention ( $68 \mathrm{~h}$ ) within the tumor after LIPO-HSV-1-tk transduction (white arrow) resembles the proposed tissue dose of vector-mediated gene expression and shows signs of necrosis (cross right column; reduced methionine uptake [MET] and glucose metabolism [FDG]) after ganciclovir treatment. Reproduced with permission from Jacobs et al. Positron-emission tomography of vector-mediated gene expression in gene therapy for gliomas. Lancet 358:727-729. Copyright (C) 2001, Elsevier Limited. All rights reserved. ${ }^{120}$

radiotherapy, whereas high ADC values indicating necrosis correlate with poorer response. ${ }^{141}$ Assessment of ADC ratios from tumor and contralateral control regions were also useful in the differentiation of radiation effects 
(high ADC ratios) from tumor recurrence or progression (low ADC ratios). ${ }^{142}$ However, it should be kept in mind that dexamethasone treatment significantly reduces the diffusivity of edematous brain, ${ }^{143}$ thus confounding the interpretation of DWIs.

Because MRS can reliably differentiate pure tumor, pure necrosis, and normal tissue, specific changes in tumor metabolite levels as detected by MRS may be predictive for the effectiveness of experimental treatment strategies. ${ }^{144}$ However, MRS alone may not be particularly helpful because most patients have mixed histological findings comprised of necrosis and tumor giving rise to inconclusive findings. In contrast, progression from low-grade to high-grade gliomas leads to a characteristically increased concentration of choline and a reduced NAA peak with high diagnostic accuracy.

Due to the relatively high cortical background activity, $\left[{ }^{18} \mathrm{~F}\right]$ FDG-PET is not suited to detect residual tumor after therapy. ${ }^{145,146}$ Similar to structural imaging, the effects of radio- and chemotherapy can be visualized by $\left[{ }^{18} \mathrm{~F}\right]$ FDG-PET only after several weeks ${ }^{147}$ with a possible transient increase of $\left[{ }^{18} \mathrm{~F}\right] \mathrm{FDG}$-uptake in the initial phase which is most likely due to infiltration of macrophages consuming $\left[{ }^{18} \mathrm{~F}\right] \mathrm{FDG} .{ }^{148-150}$ At further followup, however, recurrent tumor and progression from lowgrade to high-grade glioma can be visualized by a newly appearing hypermetabolism. ${ }^{151,152}\left[{ }^{18} \mathrm{~F}\right]$ FDG-PET has a sensitivity of $75 \%$ and a specificity of $81 \%$ for the detection of recurrent tumor versus radiation necrosis. ${ }^{153}$ Moreover, in patients after stereotactic radiotherapy for brain metastasis, coregistration of $\left[{ }^{18} \mathrm{~F}\right]$ FDG-PET images with MRI yields an improvement of the sensitivity for the detection of recurrent tumor from 65-86\%. Disadvantages of $\left[{ }^{18} \mathrm{~F}\right]$ FDG-PET include accumulation of $\left[{ }^{18} \mathrm{~F}\right] \mathrm{FDG}$ in macrophages that may infiltrate the sites having received radiation therapy. Therefore, radiation necrosis may be indistinguishable from recurrent tumor. It should be noted that in patients receiving corticosteroids as symptomatic treatment evaluation of $\left[{ }^{18} \mathrm{~F}\right] \mathrm{FDG}-$ PET may be hampered by a reduced cortex-to-white matter ratio. ${ }^{154}$

$\left[{ }^{11} \mathrm{C}\right]$ MET-PET in contrast is much better suited to follow the effects of radiation therapy, which show as a reduction of relative methionine-uptake, ${ }^{146}$ which may also be observed in animal models. ${ }^{149}$ Most importantly, $\left[{ }^{11} \mathrm{C}\right] \mathrm{MET}-\mathrm{PET}$ successfully differentiates between recurrent tumor and radiation necrosis (FIG. 6) ${ }^{155}$ with the detection of recurrent tumor at high sensitivity and high specificity. ${ }^{91,156,157}$ Similar results have been obtained with other tracers for amino acid transport, such as O-(2$\left[{ }^{18} \mathrm{~F}\right]$ fluoroethyl)-L-tyrosine and $3-\left[{ }^{123} \mathrm{I}\right]$ iodo- $\alpha$-methyl-Ltyrosine with a reliable differentiation between post-therapeutic benign lesions and tumor recurrence after treatment of low- and high-grade tumors. ${ }^{158,159}$

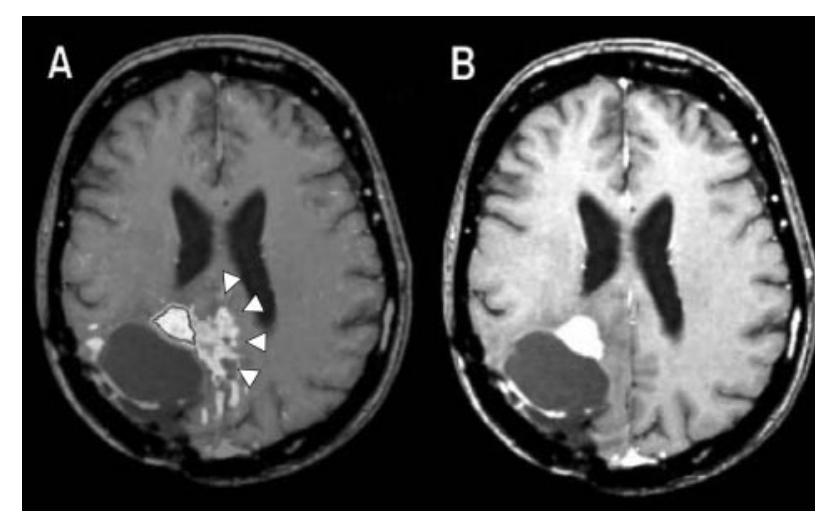

FIG. 6. Differentiation between recurrent tumor and radiation necrosis. Biopsy of this clinically worsening tumor, taken from the region with positive magnetic resonance contrast enhancement, evidenced only necrosis. However, a second biopsy from the area of increased amino acid uptake (arrowheads) revealed the findings of recurrent tumor. Reproduced with permission from Thiel et al. Enhanced accuracy in differential diagnosis of radiation necrosis by positron emission tomography-magnetic resonance imaging coregistration: technical case report. Neurosurgery 46:232-234. Copyright (C) 2000, Lippincott Williams \& Wilkins. All rights reserved. ${ }^{155}$

\section{IMAGING IN EXPERIMENTAL BRAIN TUMOR MODELS}

Imaging studies in experimental brain tumor models over the past 10 years aimed toward 1) the development of new radiotracers for cellular proliferation and protein synthesis, 2) characterization of these tracers with respect to their ability to detect responses to radio- and chemotherapy at a relatively early stage, 3 ) strategies for imaging transcriptional regulation and migration of tumor cells, and 4) imaging the expression of exogenous genes carrying a marker or therapeutic function and introduced into experimental gliomas for the purpose of developing improved gene therapeutic vectors. These experimental strategies have been reviewed in detail previously. ${ }^{67}$

New developments aim toward 1) the detection of tumor cell migration in vivo, ${ }^{160}$ 2) the establishment of in vivo assays for direct imaging of tumor-specific signal transduction pathways (e.g., p53-, E2F-1 and HIF-1- $\alpha$ regulated pathways $\left.{ }^{161-164}\right), 3$ ) the design of labeled peptides binding specifically to the cell adhesion receptor integrin $\alpha(\mathrm{v}) \beta^{3}$ or other tumor-specific antigens and of labeled bone marrow-derived endothelial precursor cells to allow highly specific tumor visualization and the study of glioma angiogenesis and neovascularization, ${ }^{165-169} 4$ ) the generation and in vivo characterization of transgenic mice with gliomas induced by signaling through Ras and Akt pathways, ${ }^{170}$ and 5) the construction of bifunctional imaging marker and therapeutic genes to allow direct assessment of therapeutic gene expression in culture and in vivo models by directly corresponding assays. ${ }^{171,172}$ Especially the design of small tumor-specific antibody fragments is an attractive way for specific detection of 
tumor cells by imaging in vivo as well as for targeted therapy by radioimmunotherapy.

Many of the current experimental protocols investigating new drug and treatment strategies for experimental gliomas include MRI, optical or PET imaging of either the distribution of therapeutic agents, ${ }^{173-175}$ or therapyinduced tumor-changes, ${ }^{171,176-184}$ with the overall attempt of designing image-guided treatments. ${ }^{120,121}$ Most intriguing for potential clinical application is the design of multifunctional nanoparticles that can be detected both by MRI and fluorescence imaging, allowing for the noninvasive preoperative assessment of the tumor and for the intraoperative visualization of tumor margins by optical imaging. ${ }^{185}$

\section{SUMMARY AND CONCLUSION}

Multimodal imaging (CT, MRI, PET, optical) and multitracer PET imaging 1) reveal the best set of anatomical, biochemical and molecular information on a specific tumor and, hence, a noninvasive diagnosis of lesion type and grade, 2) guide therapeutic choices, and 3) assess therapy effects. It should be pointed out that these imaging modalities are not competing with each other but give complementary information on various parameters of interest. Not every patient can be studied by these imaging technologies, and it is not necessary to do so. But these imaging technologies should be used together in selected patients to advance model systems and our understanding of the complex mechanism of glioma formation, behavior and migration and to allow the development and assessment of new therapeutic modalities including molecular targeted and gene therapies ("imaging-guided therapies").

Acknowledgments: This work is supported in part by the Ministerium für Schule, Wissenschaft und Forschung NorthRhine-Westphalia (MSWF 516-40000299), the Center for Molecular Medicine Cologne (CMMC-TV46), the Max-Planck Society, Germany and 6th Frame Work European Union grant European Molecular Imaging Laboratories (LSHC-CT-2004503569).

\section{REFERENCES}

1. Kleihues P, Soylemezoglu F, Schauble B, Scheithauer BW, Burger PC. Histopathology, classification, and grading of gliomas. Glia 15:211-221, 1995.

2. Louis DN, Holland EC, Cairncross JG. Glioma classification: a molecular reappraisal. Am J Pathol 159:779-786, 2001.

3. Barker FG, Israel MA. Molecular genetics. In: The gliomas (Berger MS, Wilson CB, eds), pp 39-51. Philadelphia: W.B. Saunders Co., 1999.

4. Ichimura K, Bolin MB, Goike HM, Schmidt EE, Moshref A, Collins VP. Deregulation of the p14ARF/MDM2/p53 pathway is a prerequisite for human astrocytic gliomas with G1-S transition control gene abnormalities. Cancer Res 60:417-424, 2000.

5. Morrison RS. Growth factor mediated signaling pathways. In: The gliomas (Berger MS, Wilson CB, eds), pp 52-64. Philadelphia: W.B. Saunders Co., 1999.
6. Kleihues P, Burger PC, Collins VP, Newcomb EW, Ohgaki H, Cavenee WK. Glioblastoma. In: Pathology and genetics of tumours of the nervous system. World Health Organisation Classification of Tumours (Kleihues P, Cavenee WK, eds) pp 29-39. Lyon: IARC Press, 2000.

7. Lang FF, Miller DC, Koslow M, Newcomb EW. Pathways leading to glioblastoma multiforme: a molecular analysis of genetic alterations in 65 astrocytic tumors. J Neurosurg 81:427-436, 1994.

8. Cairncross JG, Ueki K, Zlatescu MC, Lisle DK, Finkelstein DM, Hammond RR et al. Specific genetic predictors of chemotherapeutic response and survival in patients with anaplastic oligodendrogliomas. J Natl Cancer Inst 90:1473-1479, 1998.

9. DeAngelis LM, Burger PC, Green SB, Cairncross JG. Malignant glioma: who benefits from adjuvant chemotherapy? Ann Neurol 44:691-695, 1998.

10. Reifenberger G, Louis DN. Oligodendroglioma: toward molecular definitions in diagnostic neuro-oncology. J Neuropathol Exp Neurol 62:111-126, 2003.

11. Sasaki H, Zlatescu MC, Betensky RA, Johnk LB, Cutone AN, Cairncross JG, et al. Histopathological-molecular genetic correlations in referral pathologist-diagnosed low-grade "oligodendroglioma." J Neuropathol Exp Neurol 61:58-63, 2002.

12. Bakheet SM, Hassounah M, Al Watban J, Homsi M, Powe J, Larsson S. F-18 FDG PET scan of a metastatic pineoblastoma. Clin Nucl Med 24:198-199, 1999.

13. Basso U, Brandes AA. Diagnostic advances and new trends for the treatment of primary central nervous system lymphoma. Eur J Cancer 38:1298-1312, 2002.

14. Bergstrom M, Muhr C, Jossan S, Lilja A, Nyberg G, Langstrom B. Differentiation of pituitary adenoma and meningioma: visualization with positron emission tomography and [11C]-L-deprenyl. Neurosurgery 30:855-861, 1992.

15. Borbely K, Fulham MJ, Brooks RA, Di Chiro G. PET-fluorodeoxyglucose of cranial and spinal neuromas. J Nucl Med 33:19311934, 1992.

16. Chen JM, Houle S, Ang LC, Commins D, Allan K, Nedzelski J, et al. A study of vestibular schwannomas using positron emission tomography and monoclonal antibody Ki-67. Am J Otol 19:840$845,1998$.

17. Cremerius U, Bares R, Weis J, Sabri O, Mull M, Schroder JM, et al. Fasting improves discrimination of grade 1 and atypical or malignant meningioma in FDG-PET. J Nucl Med 38:26-30, 1997.

18. Fulham MJ, Melisi JW, Nishimiya J, Dwyer AJ, Di Chiro G. Neuroimaging of juvenile pilocytic astrocytomas: an enigma. $R a$ diology 189:221-225, 1993.

19. Griffeth LK, Rich KM, Dehdashti F, Simpson JR, Fusselman MJ, McGuire AH, et al. Brain metastases from non-central nervous system tumors: evaluation with PET. Radiology 186:37-44, 1993.

20. Henze M, Schuhmacher J, Hipp P, Kowalski J, Becker DW, Doll $\mathrm{J}$, et al. PET imaging of somatostatin receptors using. J Nucl Med 42:1053-1056, 2001.

21. Herholz K, Holzer T, Bauer B, Schroder R, Voges J, Ernestus RI, et al. 11C-methionine PET for differential diagnosis of low-grade gliomas. Neurology 50:1316-1322, 1998.

22. Hoffman JM, Waskin HA, Schifter T, Hanson MW, Gray L, Rosenfeld $\mathrm{S}$ et al. FDG-PET in differentiating lymphoma from nonmalignant central nervous system lesions in patients with AIDS. J Nucl Med 34:567-575, 1993.

23. Hofmann M, Maecke H, Borner R, Weckesser E, Schoffski P, Oei $\mathrm{L}$ et al. Biokinetics and imaging with the somatostatin receptor PET radioligand (68)Ga-DOTATOC: preliminary data. Eur J Nucl Med 28:1751-1757, 2001.

24. Holthoff VA, Herholz K, Berthold F, Widemann B, Schroder R, Neubauer I, et al. In vivo metabolism of childhood posterior fossa tumors and primitive neuroectodermal tumors before and after treatment. Cancer 72:1394-1403, 1993.

25. Iuchi T, Iwadate Y, Namba H, Osato K, Saeki N, Yamaura A, et al. Glucose and methionine uptake and proliferative activity in meningiomas. Neurol Res 21:640-644, 1999.

26. Kincaid PK, El Saden SM, Park SH, Goy BW. Cerebral ganglio- 
gliomas: preoperative grading using FDG-PET and 201TlSPECT. AJNR Am J Neuroradiol 19:801-806, 1998.

27. Klisch J, Juengling F, Spreer J, Koch D, Thiel T, Buchert M, et al. Lhermitte-Duclos disease: assessment with MR imaging, positron emission tomography, single-photon emission CT, and MR spectroscopy. AJNR Am J Neuroradiol 22:824-830, 2001.

28. Kracht LW, Bauer A, Herholz K, Terstegge K, Friese M, Schroder R, et al. Positron emission tomography in a case of intracranial hemangiopericytoma. J Comput Assist Tomogr 23:365-368, 1999.

29. Larcos G, Maisey MN. FDG-PET screening for cerebral metastases in patients with suspected malignancy. Nucl Med Commun 17:197-198, 1996.

30. Lassen U, Andersen P, Daugaard G, Holm S, Jensen M, Svarer C, et al. Metabolic and hemodynamic evaluation of brain metastases from small cell lung cancer with positron emission tomography. Clin Cancer Res 4:2591-2597, 1998.

31. Lippitz B, Cremerius U, Mayfrank L, Bertalanffy H, Raoofi R, Weis $\mathrm{J}$ et al. PET-study of intracranial meningiomas: correlation with histopathology, cellularity and proliferation rate. Acta Neurochir Suppl 65:108-111, 1996.

32. Lucignani G, Losa M, Moresco RM, Del Sole A, Matarrese M, Bettinardi V, et al. Differentiation of clinically non-functioning pituitary adenomas from meningiomas and craniopharyngiomas by positron emission tomography with [18F]fluoro-ethyl-spiperone. Eur J Nucl Med 24:1149-1155, 1997.

33. Meltzer CC, Townsend DW, Kottapally S, Jadali F. FDG imaging of spinal cord primitive neuroectodermal tumor. J Nucl Med 39:1207-1209, 1998.

34. Meyer PT, Spetzger U, Mueller HD, Zeggel T, Sabri O, Schreckenberger M. High F-18 FDG uptake in a low-grade supratentorial ganglioma: a positron emission tomography case report. Clin Nucl Med 25:694-697, 2000

35. Mineura K, Sasajima T, Itoh Y, Sasajima H, Kowada M, Tomura $\mathrm{N}$, et al. Blood flow and metabolism of central neurocytoma: a positron emission tomography study. Cancer 76:1224-1232, 1995.

36. Mineura K, Shioya H, Kowada M, Ogawa T, Hatazawa J, Uemura K. Subependymoma of the septum pellucidum: characterization by PET. J Neurooncol 32:143-147, 1997.

37. Muhr C, Bergstrom M, Lundberg PO, Hartman M, Bergstrom K, Pellettieri L et al. Malignant prolactinoma with multiple intracranial metastases studied with positron emission tomography. Neurosurgery 22:374-379, 1988.

38. Muhr C, Gudjonsson O, Lilja A, Hartman M, Zhang ZJ, Langstrom B. Meningioma treated with interferon- $\alpha$, evaluated with [(11)C]-L-methionine positron emission tomography. Clin Cancer Res 7:2269-2276, 2001.

39. Nyberg G, Bergstrom M, Enblad P, Lilja A, Muhr C, Langstrom B. PET-methionine of skull base neuromas and meningiomas. Acta Otolaryngol 117:482-489, 1997.

40. O'Tuama LA, Phillips PC, Strauss LC, Carson BC, Uno Y, Smith QR, et al. Two-phase [11C]L-methionine PET in childhood brain tumors. Pediatr Neurol 6:163-170, 1990.

41. Ohtani T, Takahashi A, Honda F, Ishiuchi S, Kurihara H, Inoue $\mathrm{T}$, et al. Central neurocytoma with unusually intense FDG uptake: case report. Ann Nucl Med 15:161-165, 2001.

42. Palm I, Hellwig D, Leutz M, Rentz K, Hellwig A, Kirsch CM, et al. [Brain metastases of lung cancer: diagnostic accuracy of positron emission tomography with fluorodeoxyglucose (FDGPET)]. Med Klin 94:224-227, 1999.

43. Pirotte B, Goldman S, Baleriaux D, Brotchi J. Fluorodeoxyglucose and methionine uptake in Lhermitte-Duclos disease: case report. Neurosurgery 50:404-407, 2002.

44. Provenzale JM, Arata MA, Turkington TG, McLendon RE, Coleman RE. Gangliogliomas: characterization by registered positron emission tomography-MR images. AJR Am J Roentgenol 172:1103-1107, 1999.

45. Richardson MP, Hammers A, Brooks DJ, Duncan JS. Benzodiazepine-GABA(A) receptor binding is very low in dysembryoplastic neuroepithelial tumor: a PET study. Epilepsia 42:13271334, 2001.

46. Roelcke U, Leenders KL. Positron emission tomography in pa- tients with primary CNS lymphomas. J Neurooncol 43:231-236, 1999.

47. Rohren EM, Provenzale JM, Barboriak DP, Coleman RE. Screening for cerebral metastases with FDG PET in patients undergoing whole-body staging of non-central nervous system malignancy. Radiology 226:181-187, 2003.

48. Rosenfeld SS, Hoffman JM, Coleman RE, Glantz MJ, Hanson MW, Schold SC. Studies of primary central nervous system lymphoma with fluorine-18-fluorodeoxyglucose positron emission tomography. J Nucl Med 33:532-536, 1992.

49. Sakamoto H, Nakai Y, Matsuda M, Ohashi Y, Tsuyuguchi N, Kawabe J, et al. Positron emission tomographic imaging of acoustic neuromas. Acta Otolaryngol Suppl 542:18-21, 2000.

50. Sasajima T, Mineura K, Itoh Y, Kowada M, Hatazawa J, Ogawa $\mathrm{T}$ et al. Spinal cord ependymoma: a positron emission tomographic study with (11C-methyl)-L-methionine. Neuroradiology 38:53-55, 1996.

51. Mariani L, Siegenthaler P, Guzman R, Friedrich D, Fathi AR, Ozdoba $\mathrm{C}$, et al. The impact of tumour volume and surgery on the outcome of adults with supratentorial WHO grade II astrocytomas and oligoastrocytomas. Acta Neurochir 146:441-448, 2004.

52. Provenzale JM, McGraw P, Mhatre P, Guo AC, Delong D. Peritumoral brain regions in gliomas and meningiomas: investigation with isotropic diffusion-weighted MR imaging and diffusiontensor MR imaging. Radiology 232:451-460, 2004.

53. Chang SC, Lai PH, Chen WL, Weng HH, Ho JT, Wang JS, et al. Diffusion-weighted MRI features of brain abscess and cystic or necrotic brain tumors: comparison with conventional MRI. Clin Imaging 26:227-236, 2002.

54. Preul C, Kuhn B, Lang EW, Mehdorn HM, Heller M, Link J. Differentiation of cerebral tumors using multi-section echo planar MR perfusion imaging. Eur J Radiol 48:244-251, 2003.

55. Roberts HC, Roberts TP, Brasch RC, Dillon WP. Quantitative measurement of microvascular permeability in human brain tumors achieved using dynamic contrast-enhanced MR imaging: correlation with histologic grade. AJNR Am J Neuroradiol 21: 891-899, 2000.

56. Law M, Yang S, Wang H, Babb JS, Johnson G, Cha S, et al. Glioma grading: sensitivity, specificity, and predictive values of perfusion MR imaging and proton MR spectroscopic imaging compared with conventional MR imaging. AJNR Am J Neuroradiol 24:1989-1998, 2003.

57. Law M, Yang S, Babb JS, Knopp EA, Golfinos JG, Zagzag D, et al. Comparison of cerebral blood volume and vascular permeability from dynamic susceptibility contrast-enhanced perfusion MR imaging with glioma grade. AJNR Am J Neuroradiol 25:746755, 2004.

58. Lev MH, Ozsunar Y, Henson JW, Rasheed AA, Barest GD, Harsh GR, et al. Glial tumor grading and outcome prediction using dynamic spin-echo MR susceptibility mapping compared with conventional contrast-enhanced MR: confounding effect of elevated rCBV of oligodendrogliomas. AJNR Am J Neuroradiol 25:214-221, 2004.

59. Hobbs SK, Shi G, Homer R, Harsh G, Atlas SW, Bednarski MD. Magnetic resonance image-guided proteomics of human glioblastoma multiforme. J Magn Reson Imaging 18:530-536, 2003.

60. Meyerand ME, Pipas JM, Mamourian A, Tosteson TD, Dunn JF. Classification of biopsy-confirmed brain tumors using singlevoxel MR spectroscopy. AJNR Am J Neuroradiol 20:117-123, 1999.

61. Croteau D, Scarpace L, Hearshen D, Gutierrez J, Fisher JL, Rock JP et al. Correlation between magnetic resonance spectroscopy imaging and image-guided biopsies: semiquantitative and qualitative histopathological analyses of patients with untreated glioma. Neurosurgery 49:823-829, 2001.

62. Pirzkall A, McKnight TR, Graves EE, Carol MP, Sneed PK, Wara WW et al. MR-spectroscopy guided target delineation for high-grade gliomas. Int J Radiat Oncol Biol Phys 50:915-928, 2001.

63. Ishimaru H, Morikawa M, Iwanaga S, Kaminogo M, Ochi M, Hayashi K. Differentiation between high-grade glioma and metastatic brain tumor using single-voxel proton MR spectroscopy. Eur Radiol 11:1784-1791, 2001. 
64. De Edelenyi FS, Rubin C, Esteve F, Grand S, Decorps M, Lefournier $\mathrm{V}$, et al. A new approach for analyzing proton magnetic resonance spectroscopic images of brain tumors: nosologic images. Nat Med 6:1287-1289, 2000.

65. Li X, Jin H, Lu Y, Oh J, Chang S, Nelson SJ. Identification of MRI and ${ }^{1} \mathrm{H}$ MRSI parameters that may predict survival for patients with malignant gliomas. NMR Biomed 17:10-20, 2004.

66. Herholz K, Wienhard K, Heiss WD. Validity of PET studies in brain tumors. Cerebrovasc Brain Metab Rev 2:240-265, 1990.

67. Jacobs AH, Dittmar C, Winkeler A, Garlip G, Heiss WD. Molecular imaging of gliomas. Mol Imaging 1:309-335, 2002.

68. Price P. PET as a potential tool for imaging molecular mechanisms of oncology in man. Trends Mol Med 7:442-446, 2001.

69. Heiss WD, Pawlik G, Herholz K, Wagner R, Goldner H, Wienhard K. Regional kinetic constants and cerebral metabolic rate for glucose in normal human volunteers determined by dynamic positron emission tomography of $\left[{ }^{18} \mathrm{~F}\right]$-2-fluoro-2-deoxy-D-glucose. J Cereb Blood Flow Metab 4:212-223, 1984.

70. Phelps ME. PET: the merging of biology and imaging into molecular imaging. J Nucl Med 41:661-681, 2000.

71. Sokoloff L, Reivich M, Kennedy C, Des Rosiers MH, Patlak CS, Pettigrew KD, et al. The $\left[{ }^{14} \mathrm{C}\right]$ deoxyglucose method for the measurement of local cerebral glucose utilization: theory, procedure, and normal values in the conscious and anesthetized albino rat. J Neurochem 28:897-916, 1977.

72. Heiss WD, Heindel W, Herholz K, Rudolf J, Bunke J, Jeske J, et al. Positron emission tomography of fluorine-18-deoxyglucose and image- guided phosphorus-31 magnetic resonance spectroscopy in brain tumors. J Nucl Med 31:302-310, 1990.

73. Herholz K, Heindel W, Luyten PR, denHollander JA, Pietrzyk U, Voges $\mathrm{J}$, et al. In vivo imaging of glucose consumption and lactate concentration in human gliomas. Ann Neurol 31:319-327, 1992.

74. Herholz K, Pietrzyk U, Voges J, Schroder R, Halber M, Treuer H, et al. Correlation of glucose consumption and tumor cell density in astrocytomas. A stereotactic PET study. J Neurosurg 79:853858, 1993.

75. Barker FG, Chang SM, Valk PE, Pounds TR, Prados MD. 18Fluorodeoxyglucose uptake and survival of patients with suspected recurrent malignant glioma. Cancer 79:115-126, 1997.

76. Di Chiro G, DeLaPaz RL, Brooks RA, Sokoloff L, Kornblith PL, Smith $\mathrm{BH}$ et al. Glucose utilization of cerebral gliomas measured by $[18 \mathrm{~F}]$ fluorodeoxyglucose and positron emission tomography. Neurology 32:1323-1329, 1982.

77. Goldman S, Levivier M, Pirotte B, Brucher JM, Wikler D, Damhaut $\mathrm{P}$, et al. Regional glucose metabolism and histopathology of gliomas. A study based on positron emission tomography-guided stereotactic biopsy. Cancer 78:1098-1106, 1996.

78. Kaschten B, Stevenaert A, Sadzot B, Deprez M, Degueldre C, Del Fiore G, et al. Preoperative evaluation of 54 gliomas by PET with fluorine-18-fluorodeoxyglucose and/or carbon-11-methionine. J Nucl Med 39:778-785, 1998.

79. Patronas NJ, Di Chiro G, Kufta C, Bairamian D, Kornblith PL, Simon R, et al. Prediction of survival in glioma patients by means of positron emission tomography. J Neurosurg 62:816-822, 1985.

80. Delbeke D, Meyerowitz C, Lapidus RL, Maciunas RJ, Jennings MT, Moots PL, et al. Optimal cutoff levels of F-18 fluorodeoxyglucose uptake in the differentiation of low-grade from highgrade brain tumors with PET. Radiology 195:47-52, 1995.

81. Spence AM, Muzi M, Mankoff DA, O'Sullivan SF, Link JM, Lewellen TK, et al. 18F-FDG PET of gliomas at delayed intervals: improved distinction between tumor and normal gray matter. J Nucl Med 45:1653-1659, 2004.

82. Chung JK, Kim YK, Kim SK, Lee YJ, Paek S, Yeo JS, et al. Usefulness of 11C-methionine PET in the evaluation of brain lesions that are hypo- or isometabolic on 18F-FDG PET. Eur J Nucl Med Mol Imaging 29:176-182, 2002.

83. Jager PL, Vaalburg W, Pruim J, de Vries EG, Langen KJ, Piers DA. Radiolabeled amino acids: basic aspects and clinical applications in oncology. J Nucl Med 42:432-445, 2001.

84. Ogawa T, Inugami A, Hatazawa J, Kanno I, Murakami M, Yasui $\mathrm{N}$, et al. Clinical positron emission tomography for brain tumors: comparison of fludeoxyglucose F 18 and L-methyl- ${ }^{11} \mathrm{C}$-methionine. AJNR Am J Neuroradiol 17:345-353, 1996.

85. Pauleit D, Floeth F, Tellmann L, Hamacher K, Hautzel H, Muller HW, et al. Comparison of O-(2-18F-fluoroethyl)-L-tyrosine PET and 3-123I-iodo- $\alpha$-methyl-L-tyrosine SPECT in brain tumors. J Nucl Med 45:374-381, 2004.

86. Sasaki M, Kuwabara Y, Yoshida T, Nakagawa M, Fukumura T, Mihara F, et al. A comparative study of thallium-201 SPET, carbon-11 methionine PET and fluorine-18 fluorodeoxyglucose PET for the differentiation of astrocytic tumours. Eur J Nucl Med 25:1261-1269, 1998.

87. Ishiwata K, Enomoto K, Sasaki T, Elsinga PH, Senda M, Okazumi $\mathrm{S}$ et al. A feasibility study on L-[1-carbon-11]tyrosine and L-[methyl-carbon-11]methionine to assess liver protein synthesis by PET. J Nucl Med 37:279-285, 1996.

88. Langen KJ, Muhlensiepen H, Holschbach M, Hautzel H, Jansen P, Coenen HH. Transport mechanisms of 3-[123I]iodo- $\alpha$-methylL-tyrosine in a human glioma cell line: comparison with $[3 \mathrm{H}] \mathrm{m}$ ethyl]-L-methionine. J Nucl Med 41:1250-1255, 2000.

89. Kracht LW, Friese M, Herholz K, Schroeder R, Bauer B, Jacobs $A$ et al. Methyl-[11C]-1-methionine uptake as measured by positron emission tomography correlates to microvessel density in patients with glioma. Eur J Nucl Med Mol Imaging 30:868$873,2003$.

90. Sato N, Suzuki M, Kuwata N, Kuroda K, Wada T, Beppu T et al. Evaluation of the malignancy of glioma using 11C-methionine positron emission tomography and proliferating cell nuclear antigen staining. Neurosurg Rev 22:210-214, 1999.

91. Kracht LW, Miletic H, Busch S, Jacobs AH, Voges J, Hoevels M, et al. Delineation of brain tumor extent with [11C]L-methionine positron emission tomography: local comparison with stereotactic histopathology. Clin Cancer Res 10:7163-7170, 2004.

92. Pirotte B, Goldman S, Massager N, David P, Wikler D, Vandesteene $\mathrm{A}$ et al. Comparison of $18 \mathrm{~F}-\mathrm{FDG}$ and $11 \mathrm{C}$-methionine for PET-guided stereotactic brain biopsy of gliomas. J Nucl Med 45:1293-1298, 2004.

93. De Witte O, Goldberg I, Wikler D, Rorive S, Damhaut P, Monclus $\mathrm{M}$ et al. Positron emission tomography with injection of methionine as a prognostic factor in glioma. J Neurosurg 95:746$750,2001$.

94. Nuutinen J, Sonninen P, Lehikoinen P, Sutinen E, Valavaara R, Eronen E, et al. Radiotherapy treatment planning and long-term follow-up with $[(11) \mathrm{C}]$ methionine PET in patients with lowgrade astrocytoma. Int J Radiat Oncol Biol Phys 48:43-52, 2000.

95. Ribom D, Eriksson A, Hartman M, Engler H, Nilsson A, Langstrom B et al. Positron emission tomography (11)C-methionine and survival in patients with low-grade gliomas. Cancer 92: 1541-1549, 2001.

96. Goldman S, Levivier M, Pirotte B, Brucher JM, Wikler D, Damhaut $\mathrm{P}$, et al. Regional methionine and glucose uptake in highgrade gliomas: a comparative study on PET-guided stereotactic biopsy. J Nucl Med 38:1459-1462, 1997.

97. Miwa K, Shinoda J, Yano H, Okumura A, Iwama T, Nakashima $\mathrm{T}$, et al. Discrepancy between lesion distributions on methionine PET and MR images in patients with glioblastoma multiforme: insight from a PET and MR fusion image study. J Neurol Neurosurg Psychiatry 75:1457-1462, 2004.

98. Derlon JM, Petit-Taboue MC, Chapon F, Beaudouin V, Noel $\mathrm{MH}$, Creveuil C, et al. The in vivo metabolic pattern of low-grade brain gliomas: a positron emission tomographic study using $18 \mathrm{~F}-$ fluorodeoxyglucose and 11C-L-methylmethionine. Neurosurgery 40:276-287, 1997.

99. Jacobs A. Amino acid uptake in ischemically compromised brain tissue. Stroke 26:1859-1866, 1995.

100. Krohn KA. Evaluation of alternative approaches for imaging cellular growth. Q J Nucl Med 45:174-178, 2001.

101. Mankoff DA, Dehdashti F, Shields AF. Characterizing tumors using metabolic imaging: PET imaging of cellular proliferation and steroid receptors. Neoplasia 2:71-88, 2000.

102. Mier W, Haberkorn U, Eisenhut M. [18F]FLT; portrait of a proliferation marker. Eur J Nucl Med Mol Imaging 29:165-169, 2002.

103. Shields AF, Grierson JR, Dohmen BM, Machulla HJ, Stayanoff 
JC, Lawhorn-Crews JM, et al. Imaging proliferation in vivo with [F-18]FLT and positron emission tomography. Nat Med 4:13341336, 1998.

104. Chan AA, Lau A, Pirzkall A, Chang SM, Verhey LJ, Larson D, et al. Proton magnetic resonance spectroscopy imaging in the evaluation of patients undergoing $\gamma$ knife surgery for Grade IV glioma. J Neurosurg 101:467-475, 2004.

105. Grosu AL, Lachner R, Wiedenmann N, Stark S, Thamm R, Kneschaurek P, et al. Validation of a method for automatic image fusion (BrainLAB System) of CT data and 11C-methionine-PET data for stereotactic radiotherapy using a LINAC: first clinical experience. Int J Radiat Oncol Biol Phys 56:1450-1463, 2003.

106. Pirzkall A, Li X, Oh J, Chang S, Berger MS, Larson DA, et al. 3D MRSI for resected high-grade gliomas before RT: tumor extent according to metabolic activity in relation to MRI. Int J Radiat Oncol Biol Phys 59:126-137, 2004.

107. Stadlbauer A, Moser E, Gruber S, Nimsky C, Fahlbusch R, Ganslandt $\mathrm{O}$. Integration of biochemical images of a tumor into frameless stereotaxy achieved using a magnetic resonance imaging/magnetic resonance spectroscopy hybrid data set. J Neurosurg 101:287-294, 2004.

108. Fried I, Nenov VI, Ojemann SG, Woods RP. Functional MR and PET imaging of rolandic and visual cortices for neurosurgical planning. J Neurosurg 3:854-861, 1995.

109. Hamilton RJ, Sweeney PJ, Pelizzari CA, Yetkin FZ, Holman BL, Garada B, et al. Functional imaging in treatment planning of brain lesions. Int J Radiat Oncol Biol Phys 37:181-188, 1997.

110. Herholz K, Reulen HJ, von Stockhausen HM, Thiel A, Ilmberger $\mathrm{J}$, Kessler J, et al. Preoperative activation and intraoperative stimulation of language- related areas in patients with glioma. Neurosurgery 41:1253-1260, 1997.

111. Krings T, Reinges MH, Thiex R, Gilsbach JM, Thron A. Functional and diffusion-weighted magnetic resonance images of space-occupying lesions affecting the motor system: imaging the motor cortex and pyramidal tracts. J Neurosurg 95:816-824, 2001.

112. Nyberg G, Andersson J, Antoni G, Lilja A, Pellettieri L, Valind $\mathrm{S}$, et al. Activation PET scanning in pretreatment evaluation of patients with cerebral tumours or vascular lesions in or close to the sensorimotor cortex. Acta Neurochir 138:684-694, 1996.

113. Sabatini U, Pantano P, Brughitta G, Celli P, Ricci M, Lenzi G, et al. Presurgical integrated MRI/SPECT localization of the sensorimotor cortex in a patient with a low-grade astrocytoma in the rolandic area. Neuroreport 7:105-108, 1995.

114. Thiel A, Herholz K, von Stockhausen HM, van Leyen-Pilgram K, Pietrzyk U, Kessler J, et al. Localization of language-related cortex with 15O-labeled water PET in patients with gliomas. Neuroimage 7:284-295, 1998.

115. Thiel A, Herholz K, Koyuncu A, Ghaemi M, Kracht LW, Habedank B, et al. Plasticity of language networks in patients with brain tumors: a positron emission tomography activation study. Ann Neurol 50:620-629, 2001.

116. Nariai T, Senda M, Ishii K, Maehara T, Wakabayashi S, Toyama $\mathrm{H}$, et al. Three-dimensional imaging of cortical structure, function and glioma for tumor resection. J Nucl Med 38:1563-1568, 1997.

116a. Thiel A, Habedank B, Winhuisen L, Herholz K, Kessler J, Haupt WF, Heiss WD. Essential language function of the right hemisphere in brain tumor patients. Ann Neurol 57:128-131, 2005.

117. Haberg A, Kvistad KA, Unsgard G, Haraldseth O. Preoperative blood oxygen level-dependent functional magnetic resonance imaging in patients with primary brain tumors: clinical application and outcome. Neurosurgery 54:902-914, 2004.

118. Baciu M, Le Bas JF, Segebarth C, Benabid AL. Presurgical fMRI evaluation of cerebral reorganization and motor deficit in patients with tumors and vascular malformations. Eur J Radiol 46:139146, 2003.

119. Jannin P, Morandi X, Fleig OJ, Le Rumeur E, Toulouse P, Gibaud B, et al. Integration of sulcal and functional information for multimodal neuronavigation. J Neurosurg 96:713-723, 2002.

120. Jacobs A, Voges J, Reszka R, Lercher M, Gossmann A, Kracht L, et al. Positron-emission tomography of vector-mediated gene expression in gene therapy for gliomas. Lancet 358:727-729, 2001.

121. Voges J, Reszka R, Gossmann A, Dittmar C, Richter R, Garlip G, et al. Imaging-guided convection-enhanced delivery and gene therapy of glioblastoma. Ann Neurol 54:479-487, 2003.

122. Nimsky C, Fujita A, Ganslandt O, Von Keller B, Fahlbusch R. Volumetric assessment of glioma removal by intraoperative highfield magnetic resonance imaging. Neurosurgery 55:358-370, 2004.

123. Nimsky C, Ganslandt O, Von Keller B, Romstock J, Fahlbusch R. Intraoperative high-field-strength MR imaging: implementation and experience in 200 patients. Radiology 233:67-78, 2004.

124. Berman JI, Berger MS, Mukherjee P, Henry RG. Diffusion-tensor imaging-guided tracking of fibers of the pyramidal tract combined with intraoperative cortical stimulation mapping in patients with gliomas. J Neurosurg 101:66-72, 2004.

125. Clark CA, Barrick TR, Murphy MM, Bell BA. White matter fiber tracking in patients with space-occupying lesions of the brain: a new technique for neurosurgical planning? Neuroimage 20:1601$1608,2003$.

126. Henry RG, Berman JI, Nagarajan SS, Mukherjee P, Berger MS. Subcortical pathways serving cortical language sites: initial experience with diffusion tensor imaging fiber tracking combined with intraoperative language mapping. Neuroimage 21:616-622, 2004.

127. Hanson MW, Glantz MJ, Hoffman JM, Friedman AH, Burger PC, Schold SC et al. FDG-PET in the selection of brain lesions for biopsy. J Comput Assist Tomogr 15:796-801, 1991.

128. Levivier M, Goldman S, Pirotte B, Brucher JM, Baleriaux D, Luxen A et al. Diagnostic yield of stereotactic brain biopsy guided by positron emission tomography with [18F]fluorodeoxyglucose. J Neurosurg 82:445-452, 1995.

129. Pirotte B, Goldman S, Brucher JM, Zomosa G, Baleriaux D, Brotchi J et al. PET in stereotactic conditions increases the diagnostic yield of brain biopsy. Stereotact Funct Neurosurg 63:144149, 1994.

130. Pirotte B, Goldman S, David P, Wikler D, Damhaut P, Vandesteene A, et al. Stereotactic brain biopsy guided by positron emission tomography (PET) with [F-18]fluorodeoxyglucose and [C-11]methionine. Acta Neurochir Suppl 68:133-138, 1997.

131. Voges J, Herholz K, Holzer T, Wurker M, Bauer B, Pietrzyk U et al. ${ }^{11} \mathrm{C}$-methionine and ${ }^{18} \mathrm{~F}$-2-fluorodeoxyglucose positron emission tomography: a tool for diagnosis of cerebral glioma and monitoring after brachytherapy with ${ }^{125}$ I seeds. Stereotact Funct Neurosurg 69(Pt 2):129-135, 1997.

132. Lidar Z, Mardor Y, Jonas T, Pfeffer R, Faibel M, Nass D, et al. Convection-enhanced delivery of paclitaxel for the treatment of recurrent malignant glioma: a phase I/II clinical study. J Neurosurg 100:472-479, 2004.

133. de Wit MC, de Bruin HG, Eijkenboom W, Sillevis Smitt PA, van den Bent MJ. Immediate post-radiotherapy changes in malignant glioma can mimic tumor progression. Neurology 63:535-537, 2004.

134. Hoang-Xuan K, Capelle L, Kujas M, Taillibert S, Duffau H, Lejeune J, et al. Temozolomide as initial treatment for adults with low-grade oligodendrogliomas or oligoastrocytomas and correlation with chromosome 1p deletions. J Clin Oncol 22:3133-3138, 2004.

135. Kumar AJ, Leeds NE, Fuller GN, Van Tassel P, Maor MH, Sawaya RE, et al. Malignant gliomas: MR imaging spectrum of radiation therapy- and chemotherapy-induced necrosis of the brain after treatment. Radiology 217:377-384, 2000.

136. Vos MJ, Uitdehaag BM, Barkhof F, Heimans JJ, Baayen HC, Boogerd W, et al. Interobserver variability in the radiological assessment of response to chemotherapy in glioma. Neurology 60:826-830, 2003.

137. Chiocca EA, Abbed KM, Tatter S, Louis DN, Hochberg FH, Barker F, et al. A phase I open-label, dose-escalation, multiinstitutional trial of injection with an E1B-Attenuated adenovirus, ONYX-015, into the peritumoral region of recurrent malignant gliomas, in the adjuvant setting. Mol Ther 10:958-966, 2004.

138. Jacobs AH, Voges J, Kracht LW, Dittmar C, Winkeler A, Thomas $\mathrm{A}$, et al. Imaging in gene therapy of patients with glioma. $\mathrm{J} \mathrm{Neu-}$ rooncol 65:291-305, 2003.

139. Gossmann A, Helbich TH, Kuriyama N, Ostrowitzki S, Roberts TP, Shames DM, et al. Dynamic contrast-enhanced magnetic 
resonance imaging as a surrogate marker of tumor response to anti-angiogenic therapy in a xenograft model of glioblastoma multiforme. J Magn Reson Imaging 15:233-240, 2002.

140. Chenevert TL, Stegman LD, Taylor JM, Robertson PL, Greenberg HS, Rehemtulla A, et al. Diffusion magnetic resonance imaging: an early surrogate marker of therapeutic efficacy in brain tumors. J Natl Cancer Inst 92:2029-2036, 2000.

141. Mardor Y, Roth Y, Ochershvilli A, Spiegelmann R, Tichler T, Daniels D, et al. Pretreatment prediction of brain tumors' response to radiation therapy using high b-value diffusion-weighted MRI. Neoplasia 6:136-142, 2004.

142. Hein PA, Eskey CJ, Dunn JF, Hug EB. Diffusion-weighted imaging in the follow-up of treated high-grade gliomas: tumor recurrence versus radiation injury. AJNR Am J Neuroradiol 25: 201-209, 2004.

143. Sinha S, Bastin ME, Wardlaw JM, Armitage PA, Whittle IR. Effects of dexamethasone on peritumoural oedematous brain: a DT-MRI study. J Neurol Neurosurg Psychiatry 75:1632-1635, 2004.

144. Ross BD, Kim B, Davidson BL. Assessment of ganciclovir toxicity to experimental intracranial gliomas following recombinant adenoviral-mediated transfer of the herpes simplex virus thymidine kinase gene by magnetic resonance imaging and proton magnetic resonance spectroscopy. Clin Cancer Res 1:651-657, 1995.

145. Kim EE, Chung SK, Haynie TP, Kim CG, Cho BJ, Podoloff DA, et al. Differentiation of residual or recurrent tumors from posttreatment changes with F-18 FDG PET. Radiographics 12:269279, 1992.

146. Wurker M, Herholz K, Voges J, Pietrzyk U, Treuer H, Bauer B, et al. Glucose consumption and methionine uptake in low-grade gliomas after iodine-125 brachytherapy. Eur J Nucl Med 23:583586, 1996.

147. Brock CS, Young H, O'Reilly SM, Matthews J, Osman S, Evans $\mathrm{H}$, et al. Early evaluation of tumour metabolic response using [18F]fluorodeoxyglucose and positron emission tomography: a pilot study following the phase II chemotherapy schedule for temozolomide in recurrent high-grade gliomas. $\mathrm{Br} J$ Cancer 82: $608-615,2000$.

148. De Witte O, Hildebrand J, Luxen A, Goldman S. Acute effect of carmustine on glucose metabolism in brain and glioblastoma. Cancer 74:2836-2842, 1994.

149. Reinhardt MJ, Kubota K, Yamada S, Iwata R, Yaegashi H. Assessment of cancer recurrence in residual tumors after fractionated radiotherapy: a comparison of fluorodeoxyglucose, L-methionine and thymidine. J Nucl Med 38:280-287, 1997.

150. Yamamoto T, Nishizawa S, Maruyama I, Yoshida M, Tsuchida T, Waki A, et al. Acute effects of stereotactic radiosurgery on the kinetics of glucose metabolism in metastatic brain tumors: FDG PET study. Ann Nucl Med 15:103-109, 2001.

151. De Witte O, Levivier M, Violon P, Salmon I, Damhaut P, Wikler D Jr, et al. Prognostic value positron emission tomography with [18F]fluoro-2-deoxy-D-glucose in the low-grade glioma. Neurosurgery 39:470-476, 1996.

152. Glantz MJ, Hoffman JM, Coleman RE, Friedman AH, Hanson MW, Burger PC, et al. Identification of early recurrence of primary central nervous system tumors by $[18 \mathrm{~F}]$ fluorodeoxyglucose positron emission tomography. Ann Neurol 29:347-355, 1991.

153. Chao ST, Suh JH, Raja S, Lee SY, Barnett G. The sensitivity and specificity of FDG PET in distinguishing recurrent brain tumor from radionecrosis in patients treated with stereotactic radiosurgery. Int J Cancer 96:191-197, 2001.

154. Fulham MJ, Brunetti A, Aloj L, Raman R, Dwyer AJ, Di Chiro G. Decreased cerebral glucose metabolism in patients with brain tumors: an effect of corticosteroids. J Neurosurg 83:657-664, 1995.

155. Thiel A, Pietrzyk U, Sturm V, Herholz K, Hovels M, Schroder R. Enhanced accuracy in differential diagnosis of radiation necrosis by positron emission tomography-magnetic resonance imaging coregistration: technical case report. Neurosurgery 46:232-234, 2000.

156. Tsuyuguchi N, Takami T, Sunada I, Iwai Y, Yamanaka K, Tanaka K, et al. Methionine positron emission tomography for differentiation of recurrent brain tumor and radiation necrosis after stereotactic radiosurgery-in malignant glioma. Ann Nucl Med 18:291-296, 2004.

157. Van Laere K, Ceyssens S, Van Calenbergh F, De Groot T, Menten J, Flamen P, et al. Direct comparison of (18)F-FDG and (11)C-methionine PET in suspected recurrence of glioma: sensitivity, inter-observer variability and prognostic value. Eur J Nucl Med Mol Imaging 32:39-51, 2005.

158. Henze M, Mohammed A, Schlemmer HP, Herfarth KK, Hoffner $\mathrm{S}$, Haufe S, et al. PET and SPECT for detection of tumor progression in irradiated low-grade astrocytoma: a receiver-operating-characteristic analysis. J Nucl Med 45:579-586, 2005.

159. Popperl G, Gotz C, Rachinger W, Gildehaus FJ, Tonn JC, Tatsch K. Value of O-(2-[(18)F]fluoroethyl)- 1-tyrosine PET for the diagnosis of recurrent glioma. Eur J Nucl Med Mol Imaging 31: 1464-1470, 2004.

160. Su H, Forbes A, Gambhir SS, Braun J. Quantitation of cell number by a positron emission tomography reporter gene strategy. Mol Imaging Biol 6:139-148, 2004.

161. Doubrovin M, Ponomarev V, Beresten T, Balatoni J, Bornmann W, Finn R et al. Imaging transcriptional regulation of p53-dependent genes with positron emission tomography in vivo. Proc Natl Acad Sci USA 98:9300-9305, 2001.

162. Serganova I, Doubrovin M, Vider J, Ponomarev V, Soghomonyan $\mathrm{S}$, Beresten T, et al. Molecular imaging of temporal dynamics and spatial heterogeneity of hypoxia-inducible factor-1 signal transduction activity in tumors in living mice. Cancer Res 64:61016108, 2004.

163. Uhrbom L, Nerio E, Holland EC. Dissecting tumor maintenance requirements using bioluminescence imaging of cell proliferation in a mouse glioma model. Nat Med 10:1257-1260, 2004.

164. Wen B, Burgman P, Zanzonico P, O'donoghue J, Cai S, Finn R, et al. A preclinical model for noninvasive imaging of hypoxiainduced gene expression; comparison with an exogenous marker of tumor hypoxia. Eur J Nucl Med Mol Imaging 31:1530-1538, 2004.

165. Anderson SA, Glod J, Arbab AS, Noel M, Ashari P, Fine HA, et al. Non-invasive MR imaging of magnetically labeled stem cells to directly identify neovasculature in a glioma model. Blood 105:420-425, 2004.

166. Chen X, Park R, Shahinian AH, Tohme M, Khankaldyyan V, Bozorgzadeh $\mathrm{MH}$, et al. 18F-labeled RGD peptide: initial evaluation for imaging brain tumor angiogenesis. Nucl Med Biol 31: 179-189, 2004.

167. Haubner R, Wester HJ, Weber WA, Mang C, Ziegler SI, Goodman SL, et al. Noninvasive imaging of $\alpha(\mathrm{v}) \beta 3$ integrin expression using 18F-labeled RGD-containing glycopeptide and positron emission tomography. Cancer Res 61:1781-1785, 2001.

168. Sundaresan G, Yazaki PJ, Shively JE, Finn RD, Larson SM, Raubitschek AA, et al. 124I-labeled engineered anti-CEA minibodies and diabodies allow high-contrast, antigen-specific smallanimal PET imaging of xenografts in athymic mice. $J$ Nucl Med 44:1962-1969, 2003.

169. van Waarde A, Buursma AR, Hospers GA, Kawamura K, Kobayashi T, Ishii $\mathrm{K}$, et al. Tumor imaging with $2 \sigma$-receptor ligands, 18F-FE-SA5845 and 11C-SA4503: a feasibility study. J Nucl Med 45:1939-1945, 2004.

170. Koutcher JA, Hu X, Xu S, Gade TP, Leeds N, Zhou XJ, et al. MRI of mouse models for gliomas shows similarities to humans and can be used to identify mice for preclinical trials. Neoplasia $4: 480-485,2002$.

171. Jacobs AH, Winkeler A, Hartung M, Slack M, Dittmar C, Kummer C, et al. Improved HSV-1 amplicon vectors for proportional coexpression of PET marker and therapeutic genes. Hum Gene Ther 14:277-297, 2003.

172. Ponomarev V, Doubrovin M, Serganova I, Vider J, Shavrin A, Beresten T, et al. A novel triple-modality reporter gene for wholebody fluorescent, bioluminescent, and nuclear noninvasive imaging. Eur J Nucl Med Mol Imaging 31:740-751, 2004.

173. Hamstra DA, Lee KC, Tychewicz JM, Schepkin VD, Moffat BA, Chen $\mathrm{M}$ et al. The use of $19 \mathrm{~F}$ spectroscopy and diffusionweighted MRI to evaluate differences in gene-dependent enzyme prodrug therapies. Mol Ther 10:916-928, 2004. 
174. Mamot C, Nguyen JB, Pourdehnad M, Hadaczek P, Saito R, Bringas JR et al. Extensive distribution of liposomes in rodent brains and brain tumors following convection-enhanced delivery. J Neurooncol 68:1-9, 2004.

175. Saito R, Bringas JR, McKnight TR, Wendland MF, Mamot C, Drummond DC, et al. Distribution of liposomes into brain and rat brain tumor models by convection-enhanced delivery monitored with magnetic resonance imaging. Cancer Res 64:2572-2579, 2004.

176. Grohn OH, Valonen PK, Lehtimaki KK, Vaisanen TH, Kettunen MI, Yla-Herttuala S, et al. Novel magnetic resonance imaging contrasts for monitoring response to gene therapy in rat glioma. Cancer Res 63:7571-7574, 2003.

177. Rehemtulla A, Stegman LD, Cardozo SJ, Gupta S, Hall DE, Contag $\mathrm{CH}$, et al. Rapid and quantitative assessment of cancer treatment response using in vivo bioluminescence imaging. Neoplasia 2:491-495, 2000.

178. Ross BD, Chenevert TL, Garwood M, Kim B, Stegman LD, Ben Yoseph O, et al. Evaluation of (E)-2'-deoxy-2'-(fluoromethylene)cytidine on the 9L rat brain tumor model using MRI. NMR Biomed 16:67-76, 2003.

179. Rubin JB, Kung AL, Klein RS, Chan JA, Sun Y, Schmidt K, et al. A small-molecule antagonist of CXCR4 inhibits intracranial growth of primary brain tumors. Proc Natl Acad Sci USA 100: 13513-13518, 2003.

180. Schmidt KF, Ziu M, Schmidt NO, Vaghasia P, Cargioli TG,
Doshi S, et al. Volume reconstruction techniques improve the correlation between histological and in vivo tumor volume measurements in mouse models of human gliomas. $J$ Neurooncol 68:207-215, 2004.

181. Schmidt NO, Ziu M, Carrabba G, Giussani C, Bello L, Sun Y, et al. Antiangiogenic therapy by local intracerebral microinfusion improves treatment efficiency and survival in an orthotopic human glioblastoma model. Clin Cancer Res 10:1255-1262, 2004.

182. Sun Y, Schmidt NO, Schmidt K, Doshi S, Rubin JB, Mulkern $\mathrm{RV}$, et al. Perfusion MRI of U87 brain tumors in a mouse model. Magn Reson Med 51:893-899, 2004.

183. Valonen PK, Lehtimaki KK, Vaisanen TH, Kettunen MI, Grohn $\mathrm{OH}$, Yla-Herttuala S, et al. Water diffusion in a rat glioma during ganciclovir-thymidine kinase gene therapy-induced programmed cell death in vivo: correlation with cell density. J Magn Reson Imaging 19:389-396, 2004.

184. Vooijs M, Jonkers J, Lyons S, Berns A. Noninvasive imaging of spontaneous retinoblastoma pathway-dependent tumors in mice. Cancer Res 62:1862-1867, 2002.

185. Kircher MF, Mahmood U, King RS, Weissleder R, Josephson L. A multimodal nanoparticle for preoperative magnetic resonance imaging and intraoperative optical brain tumor delineation. Cancer Res 63:8122-8125, 2003.

186. Jacobs AH. PET in gliomas. In: Neuroonkologie (Schlegel U, Weller M, Westphal M, eds.), pp 72-76. Thieme-Verlag, 2003. 